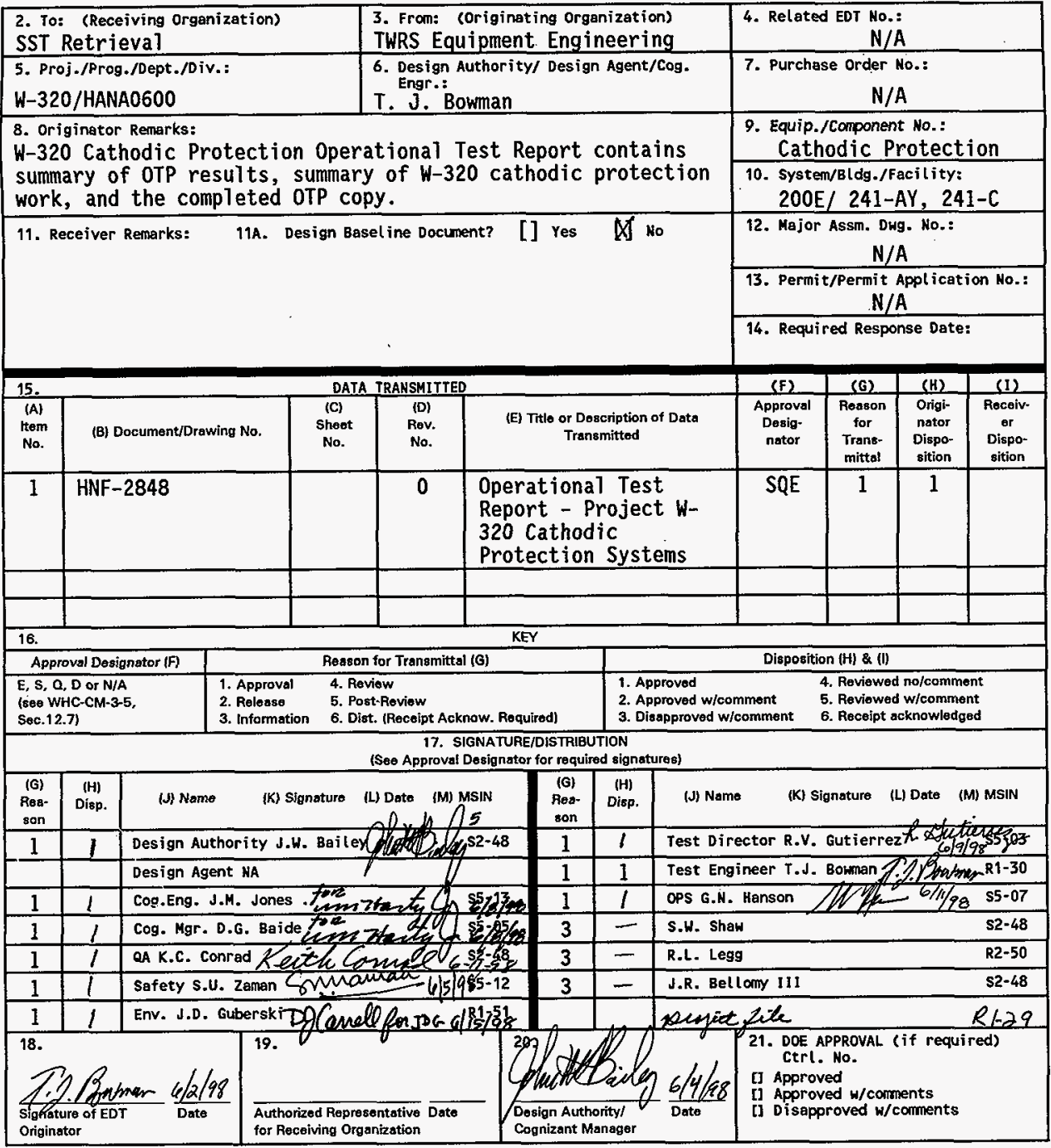

BD-7400-172-2 (05/96) GEF097 
HNF-2848, Rev. 0

\section{Operational Test Report - Project W-320 Cathodic Protection Systems}

T. : J. Bowman

Lockheed Martin Hanford Corporation, Richland, WA 99352

U.S. Department of Energy Contract DE-AC06-96RL13200

EDT/ECN: 625012

Org Code: 74711

UC: 506

B\&R Code: EW3130010

Charge Code: D2MPJ/HANA0600

Total Pages: 55

Key Words: cathodic protection, polarization, rectifiers, piping encasement

Abstract: Project $W-320$ cathodic protection system operational test procedure 0TP-320-006 Rev/Mod 0-A was completed on 05/22/98. This operational test report documents the 0TP-320-006 results and documents the results of configuration testing of integrated piping and rectifier systems associated with the $W-320$ cathodic protection systems.

TRADEMARK DISCLAIMER. Reference herein to any specific commercial product, process, or service by trade name, trademark, manufacturer, or otherwise, does not necessarily constitute or imply its endorsement, recomendation, or favoring by the United States Government or any agency thereof or its contractors or subcontractors.

Printed in the United States of Anerica. To obtain copies of this document, contact: Document Control Services, P.O. Box 950, Mailstop H6-08, Richland WA 99352, Phone (509) 372-2420; Fax (509) 376-4989.

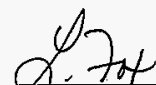

Release Approval
JUN 161998 Date

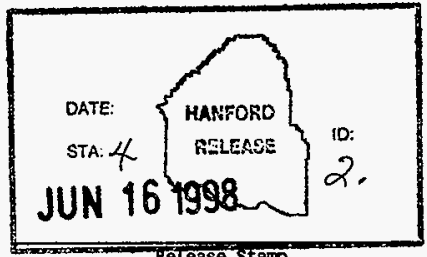

ketease stamp 
HNF-2848,

Rev. 0

Contents

Contents $\ldots \ldots \ldots \ldots \ldots \ldots \ldots \ldots \ldots \ldots \ldots \ldots \ldots \ldots \ldots \ldots \ldots \ldots, 1$

EXECUTIVE SUMMARY $\ldots \ldots \ldots \ldots \ldots \ldots \ldots \ldots \ldots \ldots \ldots \ldots \ldots \ldots \ldots \ldots \ldots, 2$

TABLE 1 - OTP-320-006 Rev/Mod A-0 Polarization Testing Results ....... 5

TABLE 2 - Work Package 2E-98-764 W-320 Cathodic Protection Start-up

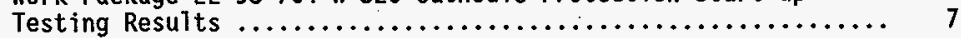

APPENDIX A - Cathodic Protection OTP testing requirements and acceptance standards of WAC 173-303-640 and NACE Standard RP0285-95 ...

8

APPENDIX B - Completed OTP-320-006 Rev/Mod A-0 (PROJECT W-320 CATHODIC PROTECTION SYSTEM OPERATIONAL TEST PROCEDURE)

10 
HNF-2848,

Rev. 0

\section{EXECUTIVE SUMMARY}

\section{ES.1 Summary of 0TP-320-006 Rev/Mod A-0 Test Results}

Washington Administrative Code (WAC) 173-303-640 specifies that corrosion protection must be designed into tank systems that treat or store dangerous wastes. Project W-320, Waste Retrieval Sluicing System (WRSS), utilizes underground encased waste transfer piping between tanks 241-C-106 and 241-AY102. Corrosion protection is afforded to the encasements of the WRSS waste transfer piping through the application of earthen ionic currents onto the surface of the piping encasements. This method of corrosion mitigation is called cathodic protection. Cathodic protection is used in conjunction with the protective coatings that are applied upon the WRSS encasement piping.

WRSS installed two new two rectifier systems (46 and 47 ) and modified one rectifier system (31). WAC 173-303-640 specifies that the proper operation of cathodic protection systems must be confirmed within six months after initial installation. The WRSS cathodic protection systems were energized to begin continuous operation on $05 / 05 / 98$. Sixteen days after the initial steady-state start-up of the WRSS rectifier systems, the operational testing was accomplished with procedure 0TP-320-006 Rev/Mod A-0 through work package 2E98-764. Rectifier 14 of the east area complex was reconfigured with the addition of testing equipment before the WRSS steady-state start-up and rectifier 14 remained in continuous operation before and during the OTP. Rectifier 14 operated within its normal range of DC voltage and amperage output during the OTP.

Proper operation of cathodic protection systems are implicitly defined in WAC 173-303-640 by meeting the recommended practices of National Association of Corrosion Engineers (NACE) Standard RP0285-95. Pertinent sections of WAC 173303-640 and NACE Standard RP0285-95 are stated in Appendix A.

The operational testing results of the $W-320$ rectifier systems are tabulated in Table 1 (OTP-320-006 Rev/Mod A-0 Polarization Testing ResuTts). All of the polarization measurements gathered across the pipes at the $W-320$ test stations meet the minimum performance standard implicitly recommended in WAC 173-303640. Measurements at a11 fourteen $W-320$ test stations showed that the underground piping was protected above the NACE RP0285-95 4.2.1.3 standard (a minimum of $100 \mathrm{mV}$ of cathodic polarization).

Measurements at twelve of the fourteen W-320 test stations showed that the underground piping was protected above the NACE RP0285-95 4.2.1.2 standard (a negative polarized potential of at least 850 millivolts relative to a saturated copper/copper sulfate electrode).

\section{ES.2 Preliminary W-320 cathodic protection test work}

Below is a summary of the preliminary test work completed prior to the performance of the OTP: 
HNF-2848,

Rev. 0

1. Acceptance Test Procedure (WHC-SD-W320-ATP-001 Rev. 0), Cathodic Protection - Rectifier 46 was completed and the Execution and Test Approval sheet was signed off on $4 / 16 / 96$.

2. Acceptance Test Procedure (WHC-SD-W320-ATP-002 Rev. 0), Cathodic Protection - Addition of 6 Anodes to Existing Rectifier 31 was completed and the Execution and Test Approval sheet was signed off on 12/5/96.

3. Acceptance Test Procedure (WHC-SD-W320-ATP-003 Rev. 0), Cathodic Protection - Rectifier 47 was completed and the Execution and Test Approval sheet was signed off on $2 / 3 / 97$.

4. Work package 2E-96-0150 was performed to secure native potential measurements at rectifier 31 test stations.

5. Hork package 2E-97-01880 was completed to resolve punch list items of the WRSS cathodic protection systems.

6. Work supplement of work package 2E-98-764 was completed. The following was accomplished with the performance of the work supplement:

a. Rectifier 31 system was reconfigured per ECN 647067 at rectifier 31 and at anode distribution boxes $A D B(31-4)$ and $A D B(31-7)$. The reconfiguration allowed the anodes around the W320 piping to be energized upon rectifier 31 start-up and isolated the DC output power of rectifier 31 from the excavation pit between the AY farm leak detector pits. The modification was continuity tested to verify the $E C N$ configuration.

b. Rectifier 8 system was reconfigured per ECN 647067 by lifting the AC feed power leads in the rectifier. The reconfiguration isolated the DC output power of rectifier 8 . The modification was voltage tested to verify the ECN configuration.

c. Resistances between the DC outputs of rectifiers $31,8,7$, and 46 were measured with the systems turned off. Al1 resistances recorded in the Mohm range, indicating no shorting between the anodes and the negative return systems.

d. Continuity was measured between the following pairs of rectifier systems: 46 to 31,7 to 31 , and 8 to 31 . Continuity testing showed that all nearby rectifier systems to the $W-320$ project were bonded to the W-320 project negative return system.

e. The polarity of rectifier 31 DC output was proven to be in the correct configuration by conducting a series of continuity tests.

$f$. The configuration of the negative return enclosure of rectifier 31 system was visually verified.

g. The continuity between the $W-320$ project and the $W-030$ project was measured and verified.

h. Electrical jumper wires were attached on test station terminals of $T(31-206)$ and $T(31-207)$ of rectifier 31 system.

$i$. System start-up testing of the rectifier 31 system was conducted.

j. An electrical jumper wire was attached on test station terminals of $T(46-3)$ of rectifier 46 system.

Table 2 documents the voltage and resistance values that were measured in the above actions.

ES.3 Completed 0TP-320-006 Rev/Mod A-0 
HNF-2848,

Rev. 0

The completed operational testing procedure is included in this OTR as Appendix B.

ES.4 Influence of rectifier systems 7, 8, and R-B220 upon OTP polarization measurements

East tank farm rectifiers 7,8 , and $\mathrm{R}-\mathrm{B} 220$ were not energized during the performance of 0PT-320-006 Rev/Mod A-0. The OTP explicitly allows these rectifiers to be non-operational during the performance of the OTP. These rectifiers had been non-operational for three years prior to the WRSS OTP. Had the rectifiers been operational during the OTP, the polarization values at the $W-320$ test stations, $T(46-14), T(31-206)$, and $T(31-207)$, would have been minimally raised. NACE RPO285-95 does not impose a maximum polarization 1 imit across the piping. The highest polarization value of the $W-320$ testing of 2.11 volts at $T(46-14)$ would be minimally raised by anode $A(41-1)$ of rectifier 7. The placement of the portable electrode around the test stations would have more influence on the polarization measurements than the operation of these rectifier systems. The logic behind this statement is as follows: The shortest distances between the anodes and test stations of the $W-320$ project and the anodes and test stations of rectifier systems 7,8 , and RB220 is documented below:

1. Distance between anode $A(41-1)$ of rectifier 7 and test station $T(46-14)$ of rectifier 46 is about 55 feet.

2. Distance between anode $A(17-4)$ of rectifier $R-B 220$ and test station $T(31-206)$ of rectifier 31 is about 55 feet.

3. Distance between anode $A(21-1)$ of rectifier 8 and test station $T(31-207)$ of rectifier 31 is about 69 feet.

The typical anode at the Hanford complex is placed a maximum of nine feet from the piping it is designed to protect. The shortest distance between the anodes of rectifiers 7,8 , and R-B220 and the test stations of the $\mathrm{W}-320$ project is 55 feet. Typically, 55 feet of physical separation will influence native potentials significantly but does not influence polarization potential significantly. This phenomena derives from the fact that it usually takes an increment of a decade of current density upon the piping to raise the polarization value across the piping 100 millivolts. Current density during native polarization measurements is a natural corrosion phenomena and is subsequently a very low value. Once the cathodic polarization value across a pipe is raised by rectifier current, it typically takes ten times the existing polarization current to raise the polarization value an additional 100 millivolts. The anode of a nearby rectifier system that is distanced 55 feet away will not deliver 10 times the existing current to the pipe. The placement of the portable electrode around the test station will typically vary the polarization measurement within the 100 millivolts range.

If rectifiers 7,8 , and R-B220 had been operational during the WRSS OTP, then the rectifiers would be required to have testing equipment installed into the rectifier circuitry. The testing equipment allows the measurement of the polarization value across the pipe and el iminates the voltage drop through the ground. Though the polarization increase is insignificant upon the WRSS 
HNF-2848,

Rev. 0

piping at the WRSS test stations with the operation of rectifier 7,8 , and RB220, the voltage drop through the ground upon delivering current would show up as polarization voltage at the WRSS test stations unless the test equipment is installed in the rectifier circuity.

Upon the start-up of rectifiers 7,8 , and $R-B 220$, it is recommended to measure the polarization values again at $T(46-14), T(31-206)$, and $T(31-207)$.

TABLE 1

0TP-320-006 Rev/Mod A-0 Polarization Testing Results

\begin{tabular}{|c|c|c|c|c|c|}
\hline & & & $\begin{array}{l}\text { NACE } \\
\text { Standard } \\
\text { RP0285-95 } \\
4.2 .1 .2 \\
\text { ( }>0.85 \\
\text { volts) }\end{array}$ & & $\begin{array}{l}\text { NACE } \\
\text { Standard } \\
\text { RP0285-95 } \\
4.2 .1 .3 \\
\text { ( > 100 } \\
\text { mi11volts) }\end{array}$ \\
\hline $\begin{array}{l}\text { RECTIFIER } \\
\text { NUMBER }\end{array}$ & $\begin{array}{l}\text { TEST } \\
\text { STATION }\end{array}$ & PIPE & $\begin{array}{l}\text { TOTAL } \\
\text { POLARIZED } \\
\text { VOLTS } \\
\end{array}$ & $\begin{array}{l}\text { NATIVE } \\
\text { VOLTS }\end{array}$ & $\begin{array}{l}\text { CATHODIC } \\
\text { POLARIZATION } \\
\text { MILLIVOLTS } \\
\end{array}$ \\
\hline 31 & $31-206$ & SL-100 & 1.34 & $0.55^{1}$ & 790 \\
\hline & & $S N-200$ & 1.36 & $0.55^{9}$ & 790 \\
\hline & $31-207$ & SL-100 & .70 & $0.44^{1}$ & 260 \\
\hline & & PSW-S508 & .71 & $0.44^{1}$ & 270 \\
\hline 47 & $47-1$ & SL-100 & 1.49 & 0.36 & 1130 \\
\hline & & $S N-200$ & 1.50 & 0.37 & 1130 \\
\hline & $47-2$ & SL-100 & 1.19 & 0.93 & 260 \\
\hline & & SN-200 & 1.18 & 0.93 & 260 \\
\hline & $47-3$ & $S L-100$ & 1.22 & 0.85 & 370 \\
\hline & $47-4$ & DR-301 & 1.21 & 0.35 & 860 \\
\hline & & SN-200 & 1.20 & 0.49 & 710 \\
\hline 46 & $46-1$ & SL-100 & 1.42 & 0.37 & 1050 \\
\hline & & $\mathrm{SN}-200$ & 1.42 & 0.37 & 1050 \\
\hline & $46-2$ & SL-100 & 1.17 & 0.37 & 800 \\
\hline
\end{tabular}


HNF-2848,

Rev. 0

\begin{tabular}{|c|c|c|c|c|c|}
\hline & & SN-200 & 1.17 & 0.37 & 800 \\
\hline \multicolumn{6}{|c|}{ OPT-320-006 Rev/Mod } \\
\hline & & & $\begin{array}{l}\text { NACE } \\
\text { Standard } \\
\text { RP0285-95 } \\
4.2 .1 .2 \\
\text { ( > } 0.85 \\
\text { volts) }\end{array}$ & & $\begin{array}{l}\text { NACE } \\
\text { Standard } \\
\text { RP0285-95 } \\
4.2 .1 .3 \\
\text { ( > 100 } \\
\text { mi11volts) }\end{array}$ \\
\hline \multirow[t]{12}{*}{46} & $46-3$ & SN-200 & .80 & 0.39 & 410 \\
\hline & & SL-100 & .80 & 0.39 & 410 \\
\hline & $46-4$ & SL-100 & .97 & 0.34 & 630 \\
\hline & & SN-200 & .97 & 0.34 & 630 \\
\hline & $46-5$ & SL-100 & 1.03 & 0.36 & 670 \\
\hline & & $\mathrm{SN}-200$ & 1.04 & 0.36 & 680 \\
\hline & $46-9$ & $S L-100$ & .91 & 0.30 & 610 \\
\hline & & $\mathrm{SN}-200$ & .91 & 0.30 & 610 \\
\hline & $46-11$ & $S L-100$ & 1.14 & 0.38 & 760 \\
\hline & & $\mathrm{SN}-200$ & 1.11 & 0.38 & 730 \\
\hline & $46-14$ & SL-100 & 2.04 & 0.50 & 1540 \\
\hline & & SN-200 & 2.11 & 0.50 & 1540 \\
\hline
\end{tabular}

1 Native volts from 2E-96-0150. Remaining native volts from ATPs. 
HNF-2848,

Rev. 0

TABLE 2

Work Package 2E-98-764 W-320 Cathodic Protection Start-up Testing Results

DC output resistance of non-energized rectifier system

Rectifier $31-1.5$ Mohms

Rectifier 8 - 15.3 Mohms

Rectifier 7 - 14.6 Mohms

Rectifier $46-2.3$ Mohms

Continuity resistance between rectifier systems

Rectifier 31 to T(46-14) - 5.3 ohms

Rectifier 31 to Rectifier $7-7.1$ ohms

Rectifier 31 to Rectifier $8-1.7$ ohms

Continuity resistance between $W-320$ and $W-030$

$\mathrm{T}(31-202)$ to $\mathrm{T}(31-207)-2.2$ ohms

System Start-up Testing of Rectifier 31 system

Average System Resistance - 1.80 ohms

Average (volt increment)/(tap setting increment) - 1.38 volts/increment

Anodic Polarization of $W-320$ rectifier systems after 16 days

Initial system 16-day system Anodic Polarization

resistance resistance Effect

Rectifier $47-\frac{6.91 \mathrm{ohms}}{9.08 \mathrm{ohms}} \quad \frac{\mathrm{Cf}}{131 \%}$

Rectifier 31 - 1.97 ohms $\quad 2.21$ ohms $\quad 112 \%$

Rectifier $46-2.28$ ohms $\quad 3.67$ ohms $\quad 161 \%$ 
HNF-2848,

Rev. 0

\begin{abstract}
APPENDIX A
Cathodic Protection OTP testing requirements and acceptance standards of WAC 173-303-640 and NACE Standard RP0285-95
\end{abstract}

\author{
Washington State Department of Ecology \\ Dangerous Waste Regulations \\ Chapter 173-303 WAC \\ Publication 92-91 \\ Amended February 1998
}

WAC 173-303-640 Tank Systems

p. 95

(1) Applicability

(a) The regulations in WAC 173-303-640 apply to owners and operators of facilities that use tank systems to treat or store dangerous waste, ...

p. 100

(6) Inspections.

(c) The owner or operator must inspect cathodic protection systems, if present, according to, at a minimum, the following schedule to ensure

that they are functioning properly:

(i) The proper operation of the cathodic protection system must be confirmed within six months after initial installation and annually thereafter; and

(ii) ...

Note: The practices described in the National Association of Corrosion

Engineers (NACE) standard. "Recommended Practice (RP-02-85)-Control of

External Corrosion on Metallic Buried, Partially Buried, or Submerged

Liquid Storage Systems," and the American Petroleum Institute (API)

Pub7ication 1632. "Cathodic Protection of Underground Petroleum Storage

Tanks and Piping Systems, " may be used, where applicable, as quidelines

in maintaining and inspecting cathodic protection systems.

(d) ....

NACE Standard RP0285-95

Item No. 21030

Standard Recommended Practice

Corrosion Control of Underground Storage Tank Systems by Cathodic Protection

Note: This standard was originally published in 1985 as "Control of External Corrosion on Metallic Buried, Partially Buried, or Submerged Liquid Storage Systems."

Section 4: Criteria for Cathodic Protection

4.2 Criteria for Steel Structures 
HNF-2848,

Rev. 0

\section{APPENDIX A (cont'd)}

Cathodic Protection OTP testing requirements and acceptance standards of WAC 173-303-640 and NACE Standard RP0285-95

4.2.1 Corrosion control can be achieved at various levels of cathodic polarization depending on the environmental conditions. However, in the absence of data which demonstrate that adequate cathodic protection has been achieved, one or more of the following shall apply:

\subsubsection{1...}

4.2.1.2 A negative polarized potential (see definition in Section 1.2) of at least $850 \mathrm{mV}$ relative to a saturated copper/copper sulfate reference electrode.

4.2.1.3 A minimum of $100 \mathrm{mV}$ of cathodic polarization. The formation or decay of polarization can be used to satisfy this criterion. 


\section{PROJECT W-320 CATHODIC PROTECTION SYSTEM OPERATIONALL TEST PROCEDURE}

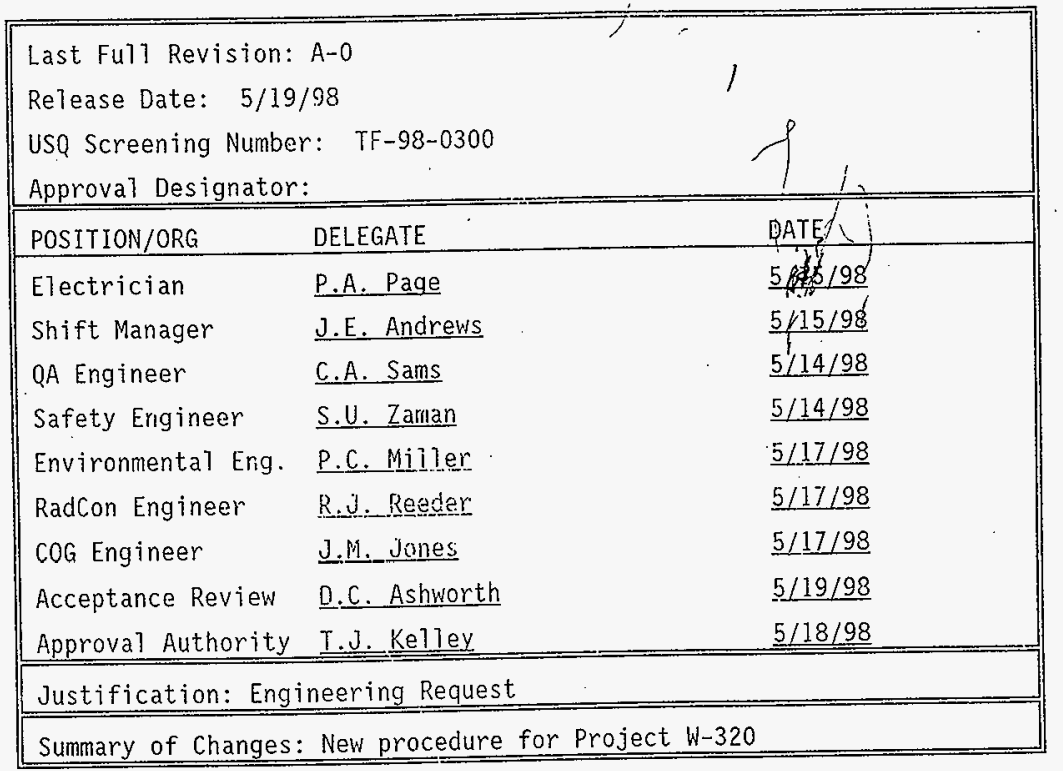




\section{TABLE OF CONTENTS

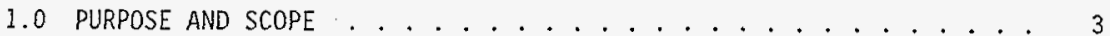

1.1 PURPOSE . . . . . . . . . . . . . . . . 3

$1.2 \mathrm{SCOPE} \ldots \ldots \ldots \ldots$

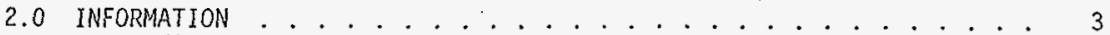

2.1 TERMS AND DEFINITIONS $\ldots \ldots \ldots$

2.2 RESPONSIBILITIES . . . . . . . . . . . . . . 4

2.3 REFERENCES . . . . . . . . . . . . . . . . . 5

2.4 GENERAL INFORMATION . . . . . . . . . . . . 5

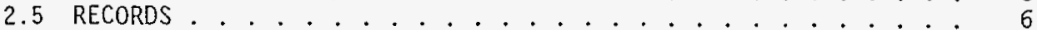

3.0 PRECAUTIONS AND LIMITATIONS . . . . . . . . . . . . . T

3.1 PERSONNEL SAFETY . . . . . . . . . . . . . . . 7

3.2 RADIATION AND CONTAMINATION CONTROL . . . . $: T_{7}$

3.3 ENVIRONMENTAL COMPLIANCE .................. 7

3.4 LIMITS . . . . . . . . . . . . . . . . . 7

4.0 PREREQUISITES . . . . . . . . . . . . . . 8

4.1 SPECIAL TOOLS, EQUIPMENT, AND SUPPLIES .......... 8

4.2 PERFORMANCE DOCUMENTS . . . . . . . . . . . . . 8

4.3 CONDITIONS AND ACTIONS ................. 9

5.0 PROCEDURE . . . . . . . . 10

5.1 INSPECT CATHODIC PROTECTION SYSTEM RECTIFIERS . . . . 10

5.2 PERFORM CATHODIC SYSTEM POLARITY/CONTINUITY TESTING . . . 14

5.3 TESTING AND ACCEPTANCE CRITERIA . ............... 17

ATTACHMENT 1 - OTP-320-006 TEST LOG . . . . . . . . . . 18

ATTACHMENT 2 - OTP-320-006 TEST EXCEPTION REPORT . . . . . . . 19

ATTACHMENT 3 - OTP-320-006 SIGNATURE LOG . . . . . . . . 20

DATA SHEET $1 \ldots \ldots \ldots$. . . . . . . . . . . . . . . 21

FIGURE 1 - CATHODIC PROTECTION RECTIFIER .......... 37

FIGURE 2 - PULSE GENERATOR - TRANSFORMER CONFIGURATION . . . . . . 38

PROCEDURE HISTORY SIGNATURE SHEET . . . . . . . . . . . . . . 39 


\subsection{PURPOSE AND SCOPE}

\subsection{PURPOSE}

This operational test procedure provides instructions for startup, adjustment, and initial service testing of the $W-320$ Cathodic Protection system.

\subsection{SCOPE}

This test inspection and testing of rectifiers installed or modified by Project W-320 (Rectifiers 31, 46 and 47 ).

other Cathodic Protection System components in ciose proximity to components installed by Project $W-320$ may al so be tested or inspected as documented in the procedure. These components are the systems associated with Rectifiers 7,8 , 14, and RB-220. Polarization values are affected (increased) by nearby systems, and stray currents are possible if nearby systems are not bonded. This is a positive affect if systems are bonded, resulting in an increased level of protection from corrosion.

Rectifier 31 represents an interface between Project $W-320$ and Project $W-030$. Due to ongoing work as part of $N-030$, Rectifier 31 will be tested in a modified configuration. On $7 \dot{y}$ anodes $A(31-161)$ to $A(31-166)$ and Anodes $A(31-196)$ to $A(31-209)$, excluding $A(31-203)$, of the oid Rectifier 31 system will be operational during the Operational Test Procedure. Project $W-320$ anodes associated with Rectifier 31 will be operational during the Operational Test Procedure. The Rectifier 31 system will be re-tested by Project $W-030$ after $W-030$ enabies $A D B(31-6)$ and $a 11$ of the subsequent connections stemming from $\operatorname{ADB}(31-6)$.

\subsection{INFORIMATION}

\subsection{TERIMS AND DEFINITIONS}

ADB - $\quad$ Anode Distribuiton Box 


\subsection{RESPONSIBILITIES}

2.2.1 Test Engineer:

- Provides technical support during testing

- Provides programming support during testing

- Reviews test documents to validate acceptance

- Records equipment status and data per this procedure

- Records data exceptions and other notes as required on the Operational Test Procedure Data Sheets

- Prepares post testing documents.

- For this Operational Test Procedure, provides identification of cathodic protection system components for equipment with missing, mislabeled; or damaged identification tags.

2.2.2 Crafts (TWRS Maintenance):

- Provide equipment for performance of this operational Test Procedure.

2.2.3 Quality Control Inspector:

- Reviews recorded test data for accuracy and completeness at completion of test.

2.2.4 Test Director:

- Verifies prerequisites complete prior to start of test

- Provides overall control of the testing process and change record authorization for this Operational Test Procedure

- Ensures all required data is collected

- Ensures safe and productive accomplishment of testing

- Ensures safe working conditions and practices

- Ensures compliance with test documents and Technical Safety Requirements/Documents (TSRs/OSDs) during testing

- Communicates and coordinates testing with DST Shift Manager

- Ensures review and approval of all modifications to test procedures are completed prior to return to testing

- Acts as direct line of communication and centralized point of control during normal, abnormal, and casualty situations

- Conducts pre-job briefings as required

- Schedules/reschedules tests as required

- Conducts pre-job system walkdowns

- Reviews test documents to validate acceptance

- Verifies all test instrumentation is within current calibration cycle. 


\subsection{REFERENCES}

- H-2-50706, Electrical Cathodic Protection Plan

- H-2-77324, Annulus Vent Piping Tk-102 241-AY Tank Farm

- H-2-91041, Cathodic Protection Plot Plan Test Stations and Jumpers

- H-2-94033, Electrical Cathodic Protection V720

- H-2-818705, Electrical Cathodic Protection Plan

- H-2-818706, Electrical Cathodic Protection Plan \#z

- H-2-818707, Electrical Cathodic Protection Plan \#2

- H-2-818708, Electrical Cathodic Protection Plan \#3

- H-2-818709, Electrical Cathodic Protection Plan Detaits

\subsection{GENERAL INFORMATION}

\subsubsection{CHANGE CONTROL}

Change control shal1 be in accordance with HNF-IP-0842.

\subsubsection{TEST EXCEPTIONS}

Components that cannot be brought into the range of acceptance specified by the applicable inspection or testing maintenance procedure shall be identified, processed and controlled as test exceptions.

Test exceptions are used to document unexpected results and identify appropriate actions, not to circumvent performance requirements.

All test exceptions shali be given a sequential number and recorded on Attachment 1, OTP-320-006 TESTT LOG.

Attachment 2, OTP-320-006 TEST EXCEPTION REPORT, shall be filled out to record and disposition each test exception.

\subsubsection{ALARM RESPONSE}

The associated maintenance procedure for this test will identify any alarms expected as a result of testing, and provide instructions for responding to those alarms.

Unexpected alarms received during testing, that are associated with this test, shall be logged as test exceptions and evaluated by the Test Director for effect on the test.

2.4.4 If changing conditions affect testing, or delays extend test duration past the end of the testing shift, the Test Director and Test Engineer need to be contacted for additional instructions. 


\subsection{GENERAL INFORMATION (Cont.)}

If during performance of this procedure, any of the following p. 15 conditions are found, IMMEDIATELY notify the assigned Test Director and Test Engineer:

- Any equipment malfunction which could prevent fulfillment of functional requirements

- Personnel error or procedural inadequacy which could prevent fulfillment of procedural requirements

- Any other unexpected anomalies.

The Test Director shall assess the effect on the system and the test, and direct either continuation of the test in the same section, proceeding to another attachment or section of the test, or suspension of the test per step 2.4.7 and establishing a safe condition for equipment.

\subsubsection{SYSTEM STATUS}

Record all changes in equipment configuration, comments and observations by participants, and any other data pertinent to the test on. Attachment 1, OTP-320-006 TEST LOG.

\subsubsection{SUSPENSION OF TEST AND RESUMING TEST}

Test Director may unilaterally, for any reason, stop testing, and place equipment in a safe condition. All suspension of testing shall be documented on Attachment 1, OTP-320-006 TEST LOG.

If a section of the test is suspended for any reason prior to completing all steps, the Test Director shall establish initial conditions necessary to resume testing for that section. Previously completed sections need not be repeated unless directed by the Test Director to establish conditions required to resume the test.

\subsection{RECORDS}

The performance copy of the Operational Test Procedure, including completed attachments shall be filed as a permanent test record (Operational Test Report). 


\subsection{PRECAUTIONS AND LIMITATIONS}

$$
\begin{gathered}
\text { HNF }-2848, \\
\text { Rev. }
\end{gathered}
$$

\subsection{PERSONNEL SAFETY}

Energized circuits and leads may be encountered during the performance of this test. Affected workers are to comply with HNF-PRO-088, "Electrical Work Safety".

\subsection{RADIATION AND CONTAMINATION CONTROL}

Work perfomed in radiological areas shall be reviewed by TWRS Radiological Control Engineering and Technical Support prior to release (HNF-IP-0422, Volume VII, Section 1.1).

\subsection{ENVIRONMENTAL COMPLIANCE}

NONE

\subsection{LIMITS}

- Rectifier 8 DC voltage output shall not exceed 50 volts. 


\subsection{PREREQUISITES}

\subsection{SPECIAL TOOLS, EQUIPIMENT, AND SUPPLIES}

NOTE - A11 Measuring and Test Equipment (M\&TE) used during performance of this procedure to collect qualitative data, with the exception of "timing devices", shall meet the following requirements:

a. Be within its current calibration cycle as evidenced by an affixed calibration label

b. Be capable of the desired range

c. Have an accuracy (consistent with state-of-the-art limitations) equal to or greater than the accuracy specified in the procedure.

4.1.1 The following tools and supplies will be needed to perform this procedure:

- Calibrated Digital Multimeter

- Water

4.1.2 The following test equipment will be supplied by the cognizant engineer:

- Waveform Analyzer (Model WFA001)

- Portable copper-copper sulfate reference electrode

\subsection{PERFORMANCE DOCUMENTS}

NONE 


\subsection{CONDITIONS AND ACTIONS}

NOTE - The pre-job briefing is an ongoing activity that is to be performed daily by the Test Director and documented in Attachment 1 , OTP-320-006 TEST LOG.

4.3.1 Perform a Pre-Job Briefing with all personnel involved in the performance of this operational test.

NOTE - Completion of the Signature Log is an ongoing requirement as new personnel become involved in the procedure.

4.3.2 All personnel to be involved with performance of this procedure have completed Attachment 3, OTP-320-006 SIGNATURE LOG.

NOTE - Maintenance and construction contraints may have limited the ability to energize nearby cathodic systems not installed by Project $W-320$ (recitifiers $7,8,14$, and $\mathrm{RB}-220$ ). If these nearby rectifier systems have not been energized a minimum of 2 weeks previous to performing this test, then they will NOT be tested as part of this operational test. The total of rectifier systems that could be operational, if no maintenance or construction constraints were present, include systems associated with the rectifiers listed in the following step.

4.3.3 Al] protected pipe lines are buried and rectifier systems to be tested have been in continuous operation for a minimum of 2 weeks prior to performing this operational test. Rectifiers 31,46 and 47 must have been operational a minimum of 2 weeks prior to continuing with this Operational Test Procedure.

\begin{tabular}{|c|c|}
\hline RECTIFIER \# & $\begin{array}{c}\text { IN OPERATION FOR } \\
2 \text { WEEKS }\end{array}$ \\
\hline 31 & $(2 / N$ \\
\hline 46 & $(/ / N$ \\
\hline 47 & $(Q / N$ \\
\hline 7 & $Y / \mathbb{N}$ \\
\hline 8 & $Y / \mathbb{N}$ \\
\hline 14 & $Q / N$ \\
\hline RB-220 & $Y / N$ \\
\hline
\end{tabular}

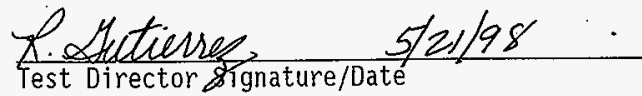




\subsection{PROCEDURE}

\subsection{INSPECT CATHODIC PROTECTION SYSTEM RECTIFIERS}

5.1.1 PERFORM Section 5.1 for each of the recitifers which have been in operation the minimum required two weeks as documented in step 4.3.3.

TABLE 1

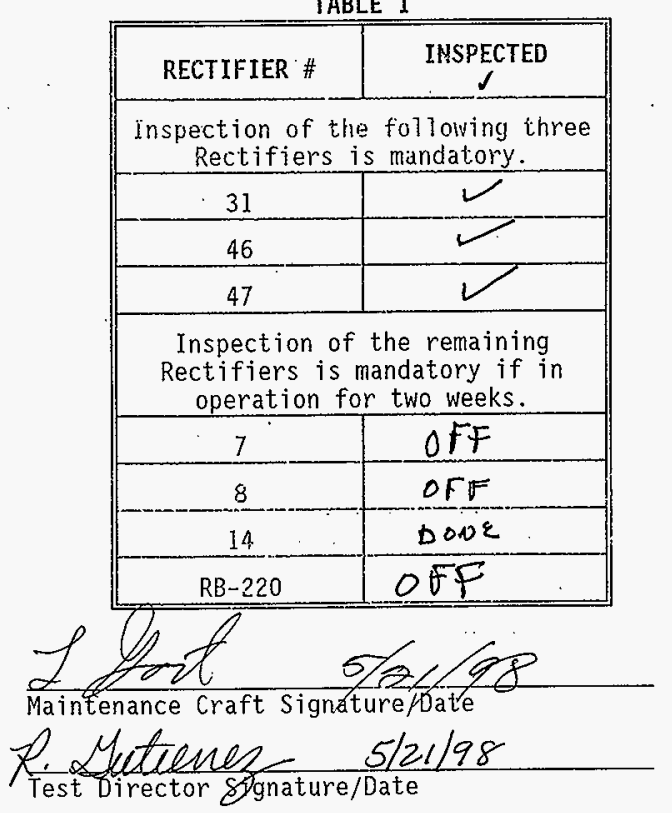

5.1.2 RECORD rectifier ID and name plate data on Data Sheet 1 . 
5.1 INSPECT CATHODIC PROTECTION SYSTEM RECTIFIERS (Cont.) Rev. O

5.1.3 INSPECT condition of rectifier AND

RECORD any discrepancies and/or actions taken on Data Sheet 1.

5.1.3.1 VISUALLY INSPECT Oi] is at the proper level.

RECORD findings in REMARKS section of data sheet.

5.1.3.2 VISUALLY INSPECT rectifier for leaks.

RECORD findings in REMARKS section of data sheet.

5.1.3.3 INSPECT oil, clarity shall be clear and nearly colorless.

RECORD murky or cloudy appearance on data sheet.

5.1.3.4 VISUALLY INSPECT for frayed and broken wiring.

RECORD deficiencies in REMARKS section of data sheet.

5.1.3.5 INSPECT gasket seal.

RECORD deficiencies in REMARKS section of data sheet.

NOTE - Pulse generators are permanentiy or temporarily installed in the rectifier circuitry. The direct current varies once every 4 seconds due to the current interruption cycle of the pulse generator. The interruption should last approximately 0.1 seconds. The voltage readings may or may not vary, depending upon the location of the pulse generator installation.

5.1.4 IF the rectifier being inspected is NOT equipped with a pulse generator, GO TO 5.1.6. 
5.1 INSPECT CATHODIC PROTECTION SYSTEM RECTIFIERS (Cont.) Rev.

5.1.5 VERIFY pulse generator configuration.

5.1.5.1 VERIFY the pulse generator's alternating current voltage selector switch is positioned to 115 volts.

5.1.5.2 ENSURE that the pulse generator's DIP switches are positioned as follows:

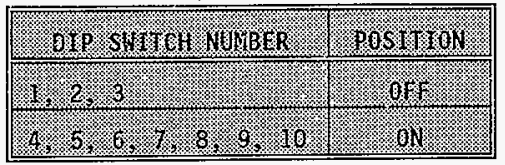

5.1.5.3 OBSERVE the voltmeter and the ammeter for the direct current output on the rectifier control panel.

5.1.5.4 IF "ON" cycle time is approximately 4 seconds AND the "OFF" cycle time is approximately 0.1 seconds, RECORD as satisfactory on Data Sheet 1 .

5.1.5.5 IF the pulse generator is NOT satisfactory, SECURE the rectifier AND NOTIFY Test Director.

NOTE - All amperage and voltage readings recorded below through step 5.1.9 shall be obtained during recitifier "On Cycle."

5.1.6 RECORD rectifier panel meter readings (volts and amps) on Data Sheet 1 .

5.1.7 RECORD DC voltage across rectifier output lugs on Data Sheet 1 .

5.1.8 CHECK ammeter reading with millivolt shunt reading. 
5.1 INSPECT CATHODIC PROTECTION SYSTEM RECTIFIERS (Cont.) ReU. 0

NOTE - For the Good-All rectifiers: The total output shunt can be identified as the one shunt with wires attached. The wires lead to the installed ammeter.

- For the Universal rectifier: The total output shunt is the shunt that is positioned horizontally and is located just below the input circuit breaker.

- The other shunts in the rectifier enclosure are installed directly above the connectors. The connectors are attached to the cables that lead to the structures and the anodes.

- The reading in the following substep should be taken by placing test leads on brass screws.

5.1.9 RECORD millivolt potential across total output shunt on Data Sheet 1

NOTE - Each shunt is labeled with the current flow that will produce a potential drop of 50 millivolts (for example: $15 \mathrm{~A} / 50 \mathrm{Mv}$ ). Actual current flow is "mV reading * Amp rating/50" (for example: $11 \mathrm{mV}$ across a $15 \mathrm{~A} / 50 \mathrm{mV}$ shunt is $11 * 15 / 50=3.3 \mathrm{Amps}$ ).

5.1.10 CALCULATE actual current flow through shunt.

5.1.11 RECORD calculated current fTow.

NOTE - Newer rectifiers are equipped with digital meters, that are factory calibrated, and are not adjustable.

5.1.12 IF recorded analog meter amprerage equals the calculated amperage, OR for digital meters, GO TO 5.1.14

5.1.13 ADJUST analog meters, if required.

5.1.13.1 ADJUST meter reading to match actual by turning sma11 screw on meter face-plate.

5.1.13.2 IF meter adjustment was made, RECORD new meter readings on Data Sheet.

5.1.14 RECORD in data sheet remarks section any discrepancy between digital meters and calculated values.

5.1.15 RECORD "As-Found" transformer tap setting. 
5.2 PERFORM CATHODIC SYSTEM POLARITY/CONTINUITY TESTING ReU.O

5.2.1 PERFORM Steps 5.2.2 through 5.2.4 for each of the Test Stations P. 23 identified in Table 2 below.

TABLE 2

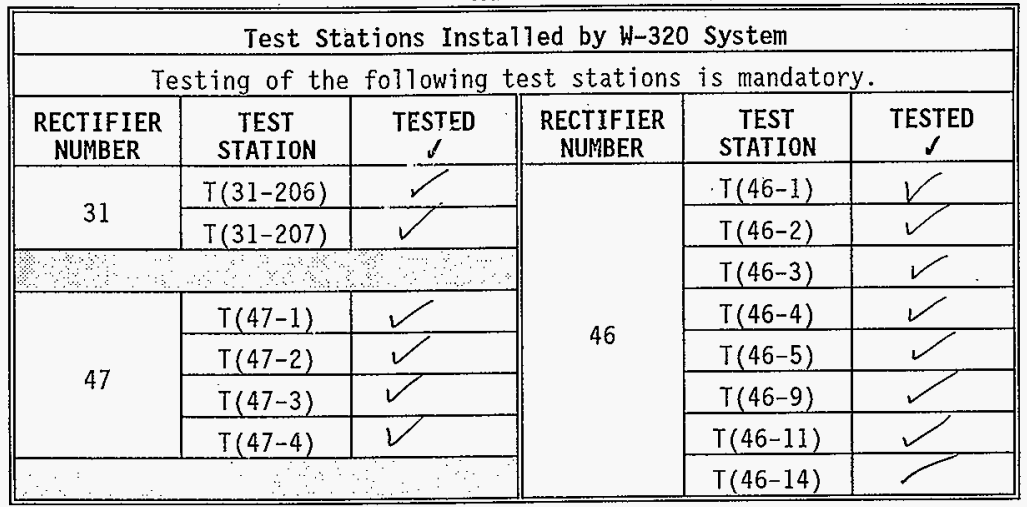

NOTES - The portabie reference electrode must be in good contact with the electrolyte in the ground to obtain valid readings. To do this, ensure that the porous plug of the electrode is in solid contact with the soil. If the test station is located in an area that is paved with asphalt, pour a small amount of water on the soil in the test station box and set the electrode in the moist soil.

- "Fish-gut" or pebbly coverings that are on top of the soil must be removed before placement of the portable electrode upon the soil.

- Wave Form Analyzer must be in the "Wave Form Analyzer" mode during testing. 


\subsection{PERFORM CATHODIC SYSTEM POLARITY/CONTINUITY TESTING RPU. 0 (Cont.)

\subsubsection{MEASURE test conductor resistance.}

NOTE - The terminals to be tested are listed on the data sheet for each individual test station.

5.2.2.1 MEASURE resistance between pairs of terminals as indicated on the applicable test station data sheet.

5.2.2.2 RECORD the structure ID (as/if labeled) and its measured resistance value (ohms) in the location identified on the appropriate test station data sheet.

5.2.2.3 REPEAT step 5.2.2.1 and 5.2.2.2 until the resistance between all terminal pairs identified on the data sheet have been measured.

5.2.3 RECORD the resistance between structures at two of the terminals as indicated on the Test Station Data Sheet.

5.2.4 MEASURE the "ON" and "OFF" potentials (relative to the portable reference electrode and relative to the designated permanent reference electrode) of each structure.

5.2.4.1 CONNECT the positive (t) lead of the Wave Form Analyzer to the portable or the permanent reference electrode terminal.

NOTE - If one of the two conductors to a specific pipe is jumpered together with a conductor to a different pipe, take potential readings on the conductor that is not jumpered.

5.2.4.2 CONNECT the common (-) lead of the Wave Form Analyzer to the test station terminals as indicated on the Test Station Data Sheet.

5.2.4.3 IF the measured resistance between the terminals is greater than 100 ohms, as evidenced by step 5.2.2.2,

CONNECT common $(-)$ Tead of the Wave Form Analyzer to each terminal by installing a jumper across the terminals identified by the Test Engineer. 


\subsection{PERFORM CATHODIC SYSTEM POLARITY/CONTINUITY TESTING} (Cont.)

NOTE - Polarities displayed on the Wave Form Analyzer represent the "soil-to-pipe" convention.

- ALL DISPLAYED voltage readings MUST be POSITIVE.

- The Wave Form Analyzer must be set in the "Wave Form Analyzer" mode during testing.

5.2.4.4 RECORD the "ON" and "OFF" potential readings for the terminals on the data sheet.

5.2.4.5 REPEAT steps 5.2.4.1 through 5.2.4.4 unti] BOTH the portable reference electrode measurements AND the permanent reference electrode measurements have been recorded for each of the terminal pairs indicated on the Test Station Data Sheet.

5.2.5 Rectifiers are energized. Al1 components and equipment are secure from testing. Testing is complete.

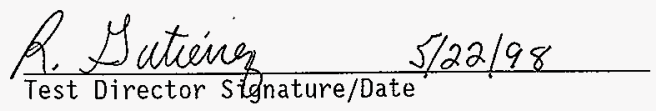




\section{sb/ee/s}

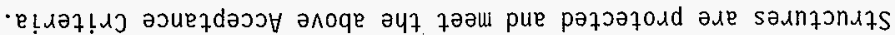

$\tau \cdot \varepsilon \cdot 9$

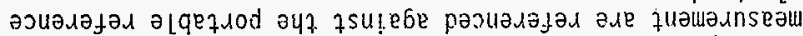

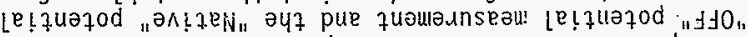

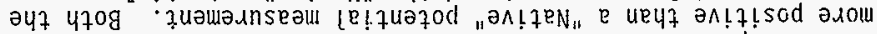

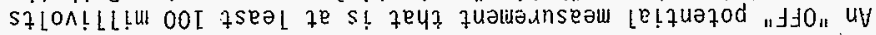

40

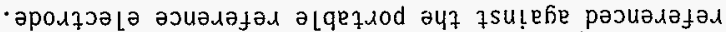

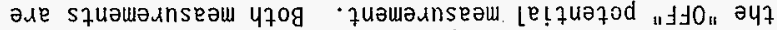

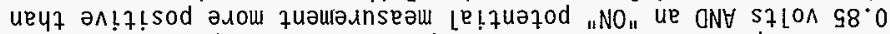

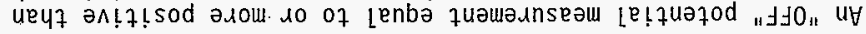

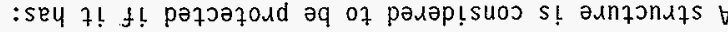

$\left[\cdot \varepsilon^{*} \mathrm{~g}\right.$

- иo!zuanuos

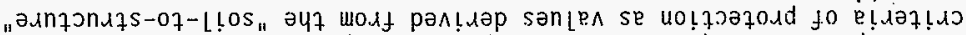

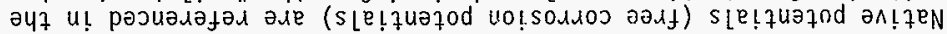

- Uo!quanuos s!47

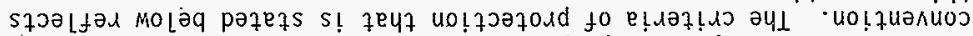

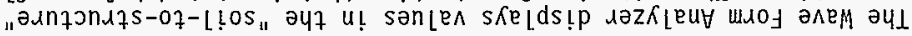

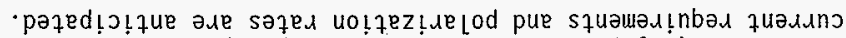

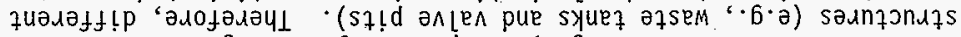

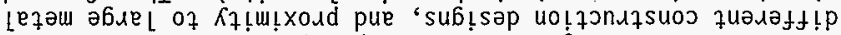

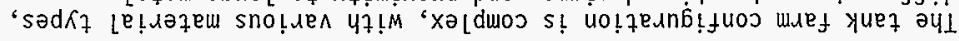
$92 \cdot d$ Q nay $\forall I 4 \exists \perp I Y \supset \exists \supset N \forall \perp d \exists \supset \supset \forall$ aN $\forall$ ONILS ' 8 h $8 \mathrm{~L}-1 \mathrm{NH}$ 


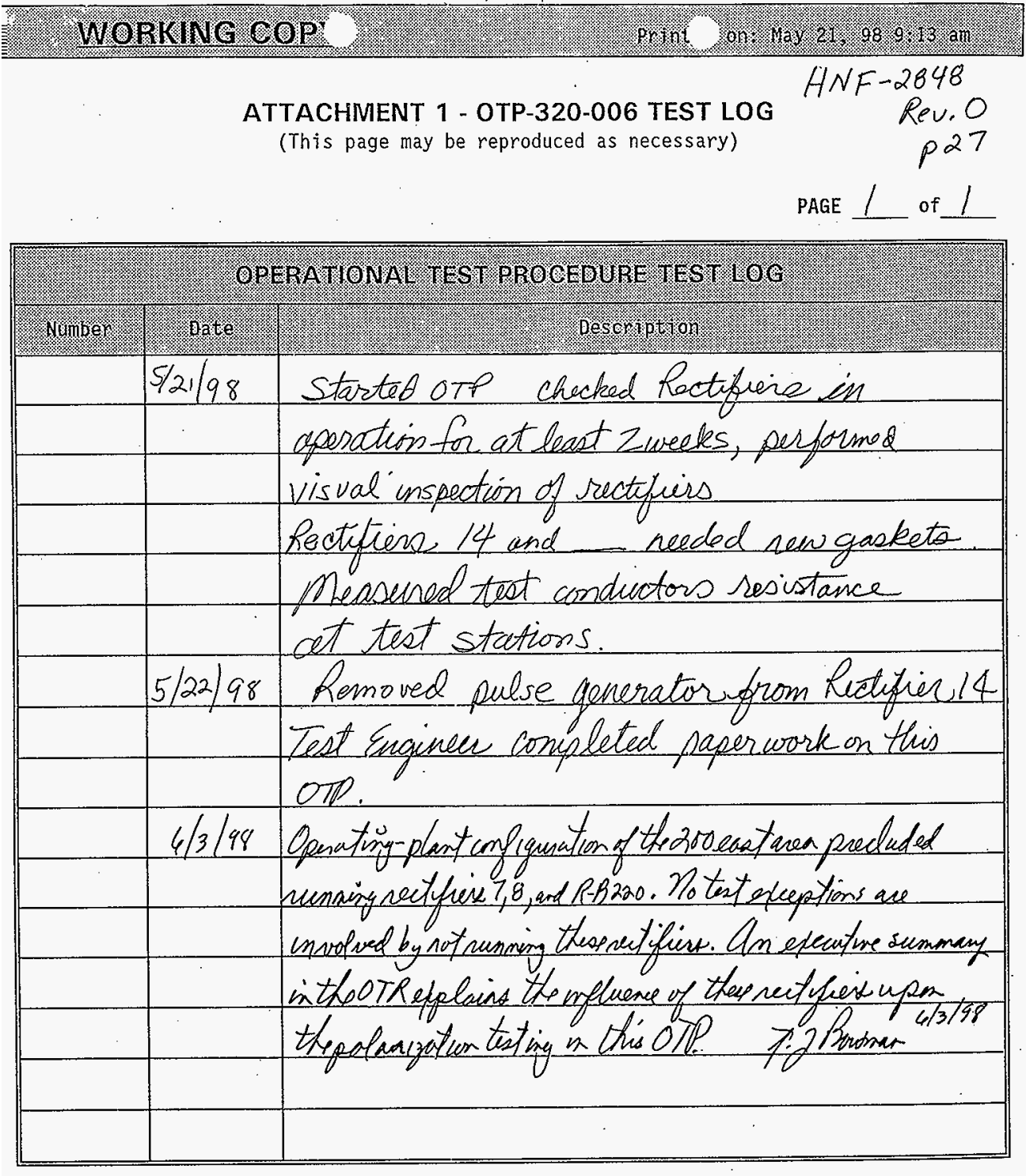

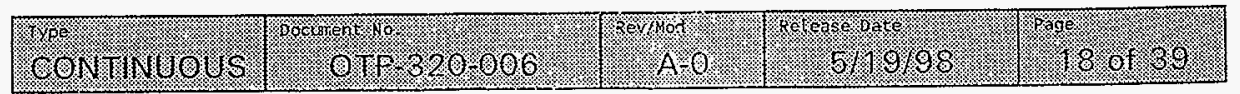




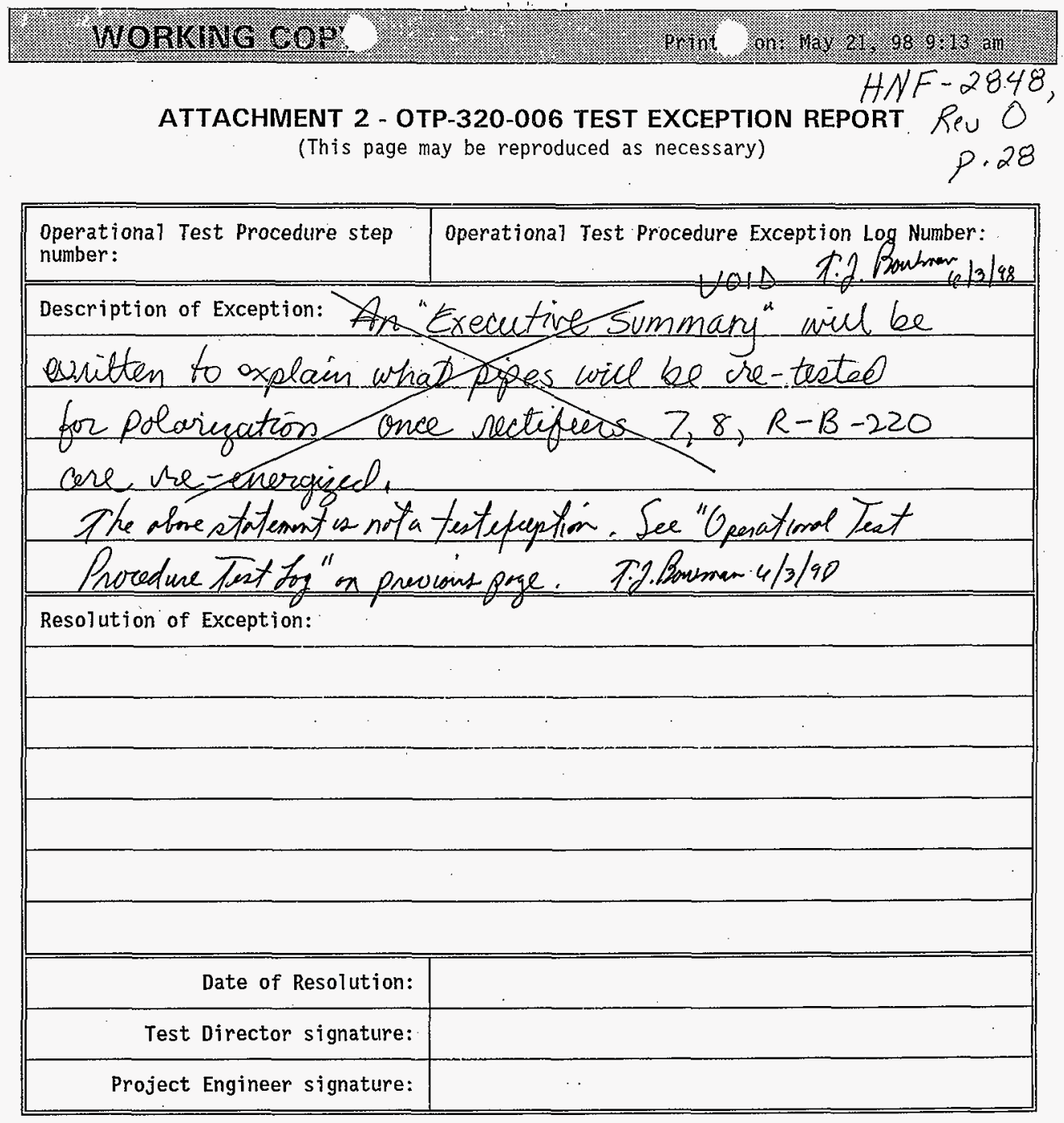

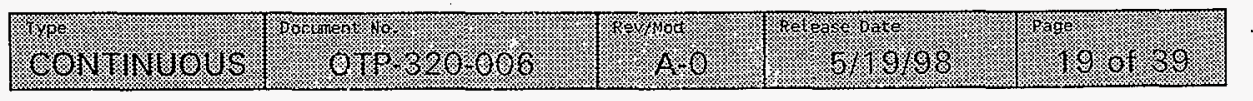


All personnel participating in the performance of this operational test procedure shall enter their printed name, signature and initials below.

NAME (PRINT)

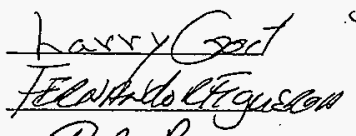

72 Bownar

RoBert TAYULR

Bich Gutierrez

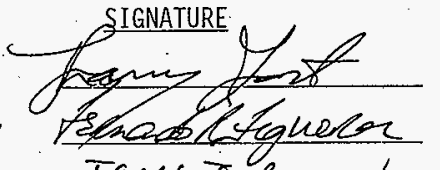

TERLY I Buwman

Bobert Larlo $F O H / A I$

R. Stutserrez
INITIALS

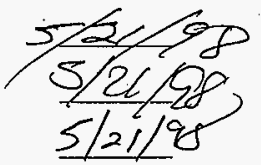

5.2194

$5-2198$ 
DATA SHEET 1 HNF -2848
Rev. 0
$p .30$

rectifier ID: Rectifies No.14

DATE: $5 \mid 21 / 98$

\begin{tabular}{|l|c|}
\hline \multicolumn{2}{|c|}{ RECTIFIER NAME PLATE DATA } \\
\hline MAKE & CZOODALL ELECTRIC \\
\hline MODEL & CSOYTF- $120-40 \quad$ ENTZ \\
\hline SERIAL NUMBER & $86 C 2340$ \\
\hline $\begin{array}{l}\text { AC LINE INPUT } \\
\text { VOLTAGE }\end{array}$ & 480 \\
\hline AC LINE FREQUENCY & 60 \\
\hline NUMBER OF PHASES & 3 \\
\hline DC OUTPUT VOLTAGE & 120 \\
\hline DC OUTPUT CURRENT & 40 \\
\hline
\end{tabular}

\begin{tabular}{|l|l|l|l|}
\hline \multicolumn{3}{|c|}{ RECTIFIER INSPECTION POINTS } \\
\hline STEP \# & INSPECTION POINT & YES & NO \\
\hline 5.1 .3 .1 & Oil Level OK? & Any oil leaks in rectitier? & \\
\hline 5.1 .3 .2 & Is the oil clear? & \\
\hline 5.1 .3 .3 & Any frayed or broken wires visable? & \\
\hline 5.1 .3 .4 & Is the gasket seal in need of repair? & \\
\hline 5.1 .3 .5 & &
\end{tabular}

PULSE GENERATOR INSPECTION

\begin{tabular}{|c|c|c|c|c|}
\hline STEP \# & INSPECTION POINT & YES & . $\mathrm{NO}$ & NA \\
\hline 5.1 .4 & Pulse generator installed? & & & \\
\hline 5.1 .5 .1 & AC Voltage selector switch set correctly? & & & \\
\hline 5.1 .5 .2 & DIP switches set correctly? & & & \\
\hline 5.1 .5 .3 & Pulse generator cycle time satisfactory? & & & \\
\hline
\end{tabular}




\begin{tabular}{|c|c|c|c|}
\hline \multicolumn{4}{|c|}{ RECTIFIER "ON CYCLE" } \\
\hline STEP \# & INSPECTION POINT Rectifier No.14 & \multicolumn{2}{|l|}{$5 1 2 1 \longdiv { 9 8 }$} \\
\hline 5.1 .6 & Readings on rectifier installed meters & $Q \bigcirc$ volts & 15 \\
\hline 5.1 .7 & Rectifier output voltage using multimeter & \multicolumn{2}{|c|}{19.51} \\
\hline 5.1 .9 & Millivolt potential across total output shunt & \multicolumn{2}{|c|}{12.5} \\
\hline 5.1 .11 & Calculate output current $50 \mathrm{~A} / 50 \mathrm{mv}$ & \multicolumn{2}{|c|}{12.5} \\
\hline 5.1 .13 & Meter adjustment required? (Circle one) & Yes & No \\
\hline 5.1 .13 .2 & Meter readings after adjustment (or NA) & \multicolumn{2}{|c|}{12.2} \\
\hline 5.1 .15 & "As Found" rectifier tap setting & \multicolumn{2}{|c|}{$A-3$} \\
\hline
\end{tabular}

REMARKS:

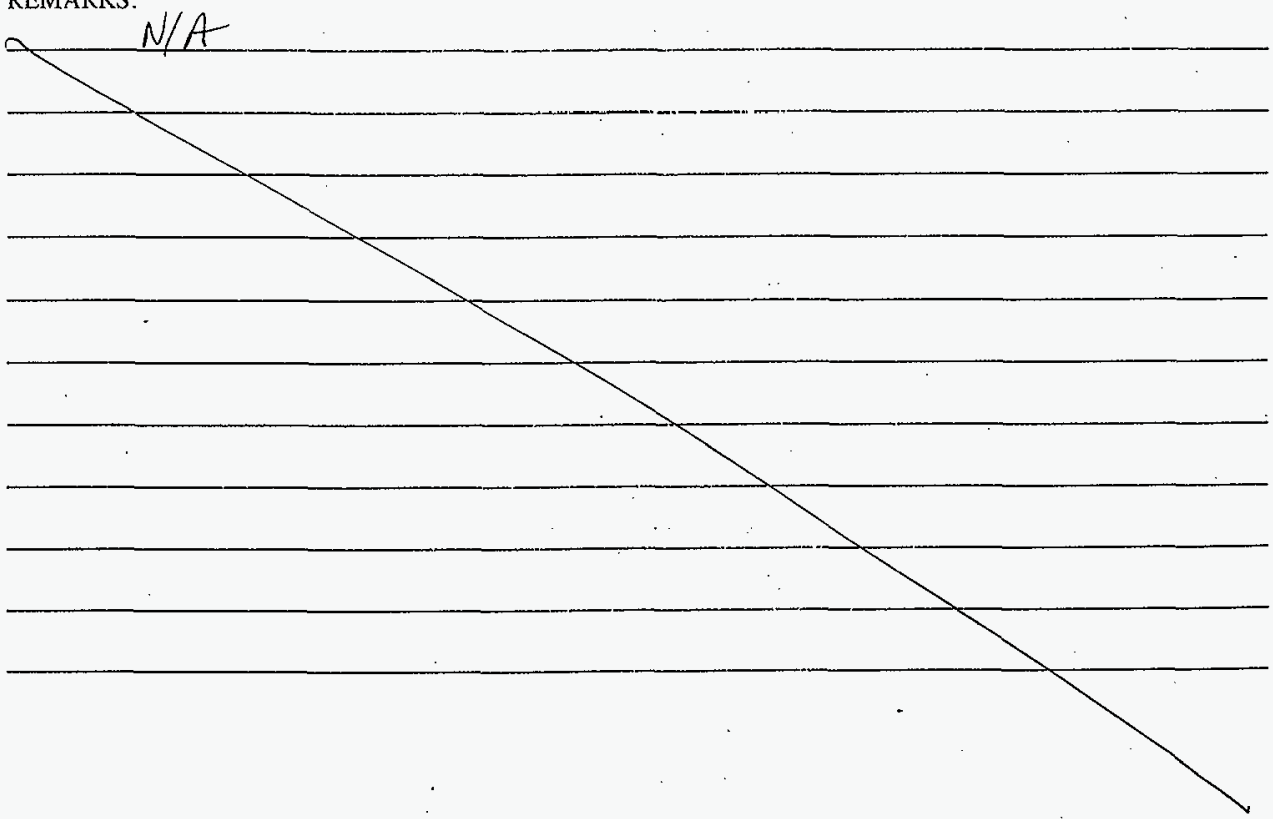




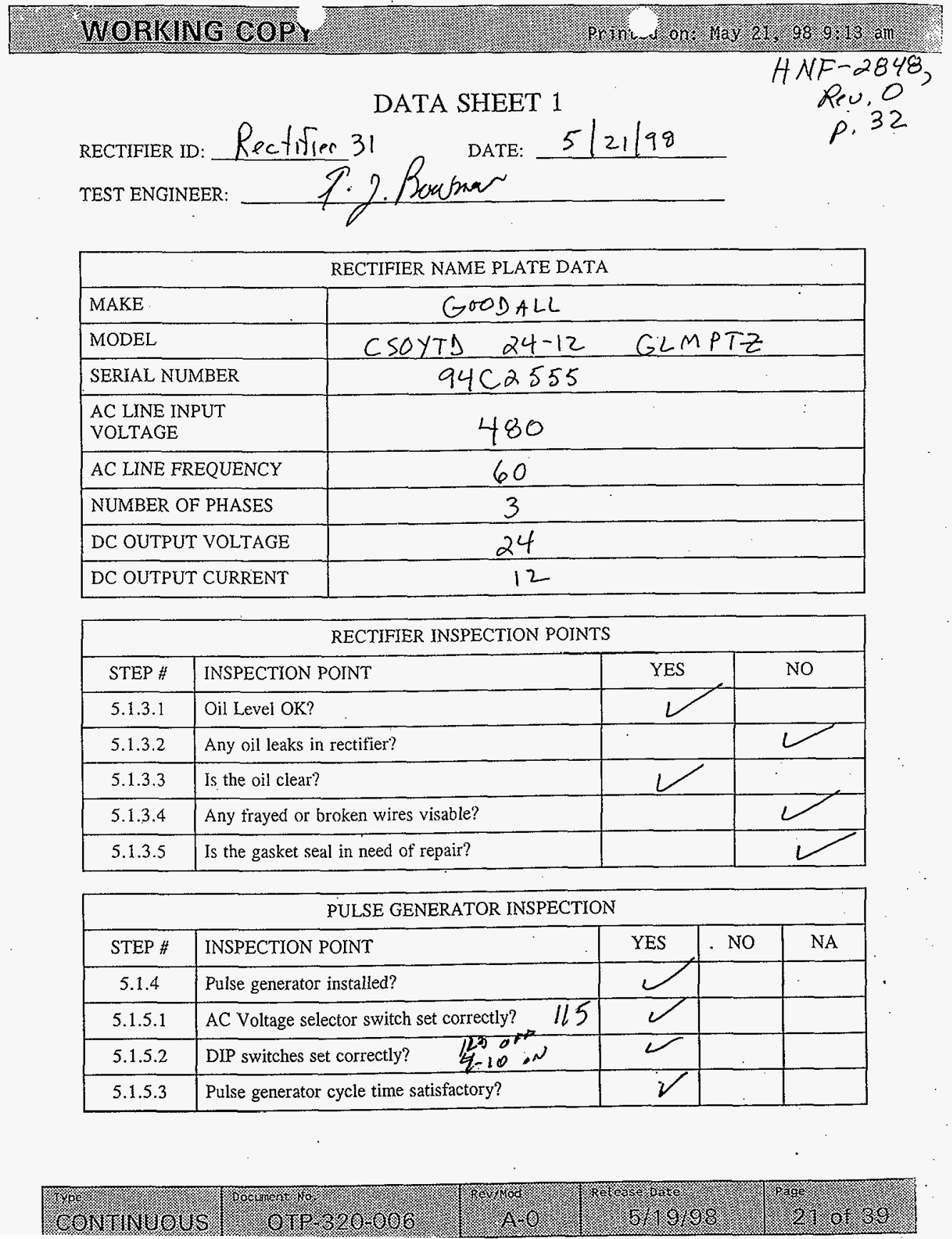




\section{DATA SHEET 1}

HNF-2848, (CONTINUED)

\begin{tabular}{|c|c|c|c|}
\hline \multicolumn{4}{|c|}{ RECTIFIER "ON CYCLE" } \\
\hline STEP \# & INSPECTION POINT Rectifier 31 & \multicolumn{2}{|c|}{5121198} \\
\hline 5.1 .6 & Readings on rectifier installed meters & 8,6 volts & 3.8 Amps \\
\hline $5.1 .7^{\circ}$ & Rectifier output voltage using multimeter & \multicolumn{2}{|c|}{8.6} \\
\hline 5.1 .9 & Millivolt potential across total output shunt & \multicolumn{2}{|c|}{3.9} \\
\hline 5.1 .11 & Calculate output current , $50 \% / 50_{1} \mathrm{U}$ & \multicolumn{2}{|c|}{3.9} \\
\hline 5.1 .13 & Meter adjustment required? (Circle one) & Yes & \\
\hline 5.1 .13 .2 & Meter readings after adjustment (or NA) & \multicolumn{2}{|c|}{$N A$} \\
\hline 5.1 .15 & "As Found" rectifier tap setting & \multicolumn{2}{|c|}{$B-2$} \\
\hline
\end{tabular}

\section{REMARKS:}

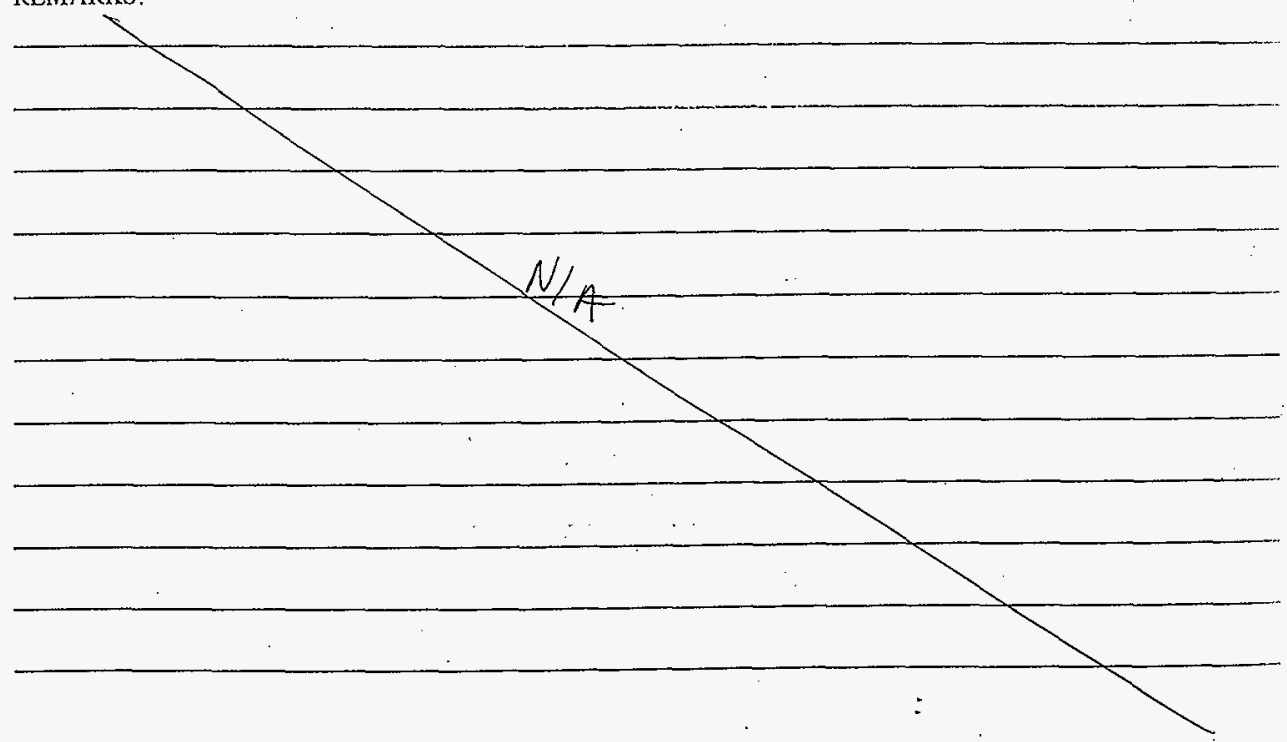




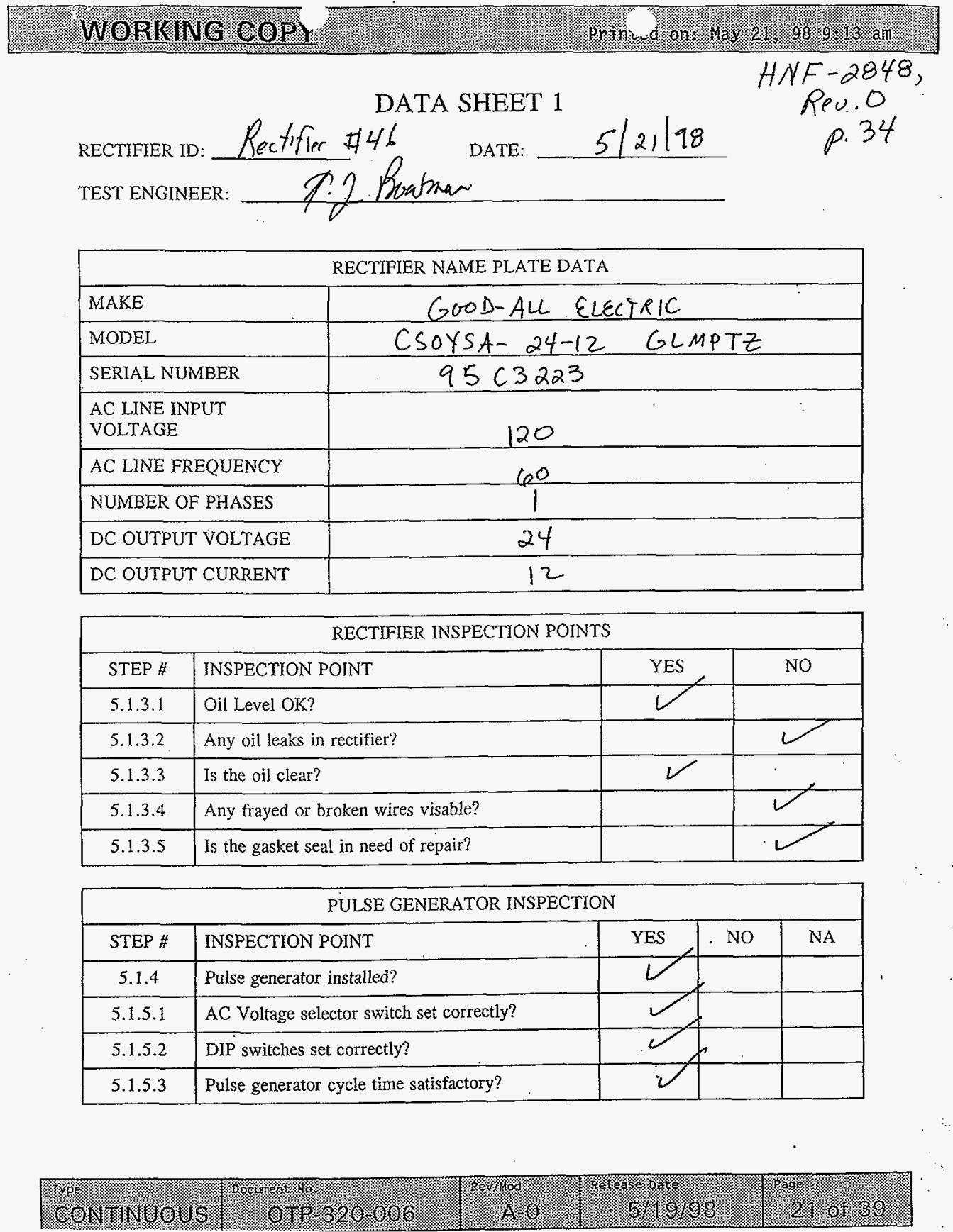




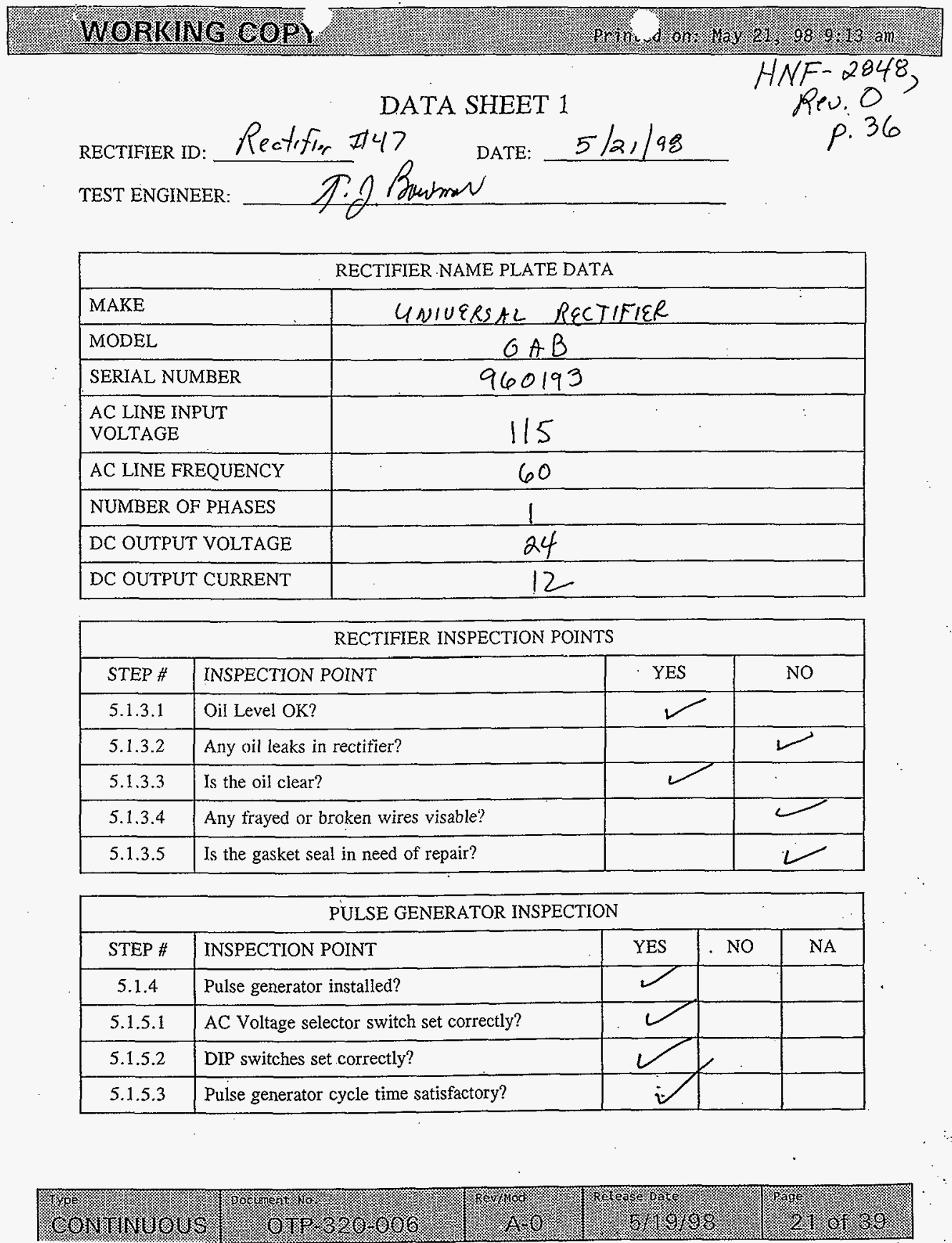


$\therefore$
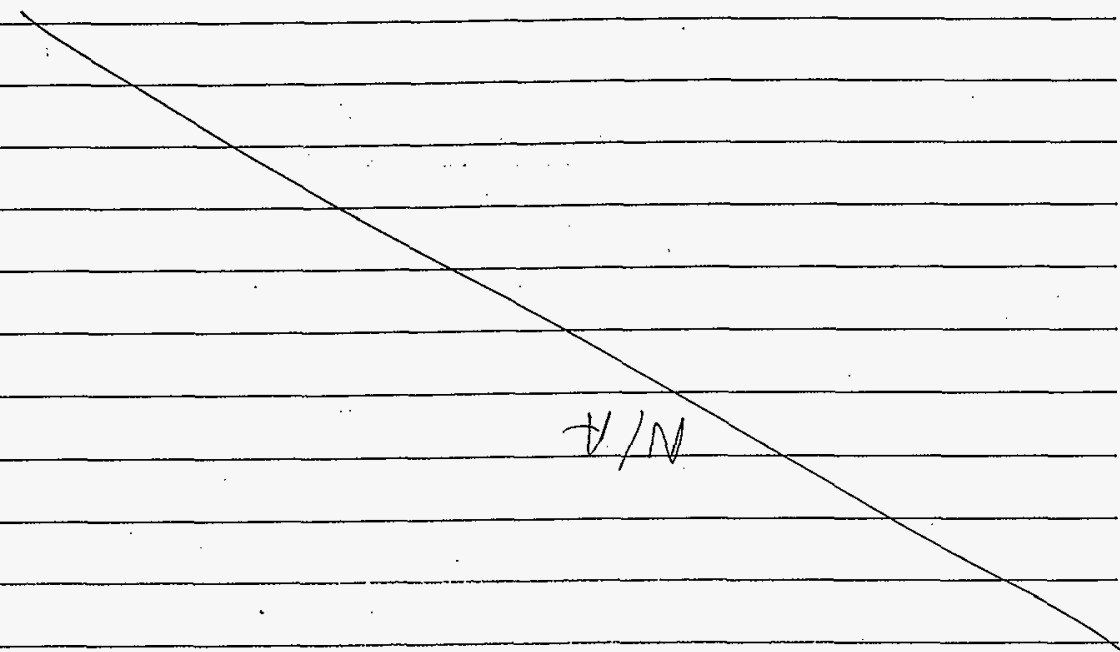

:SYप्d WWG

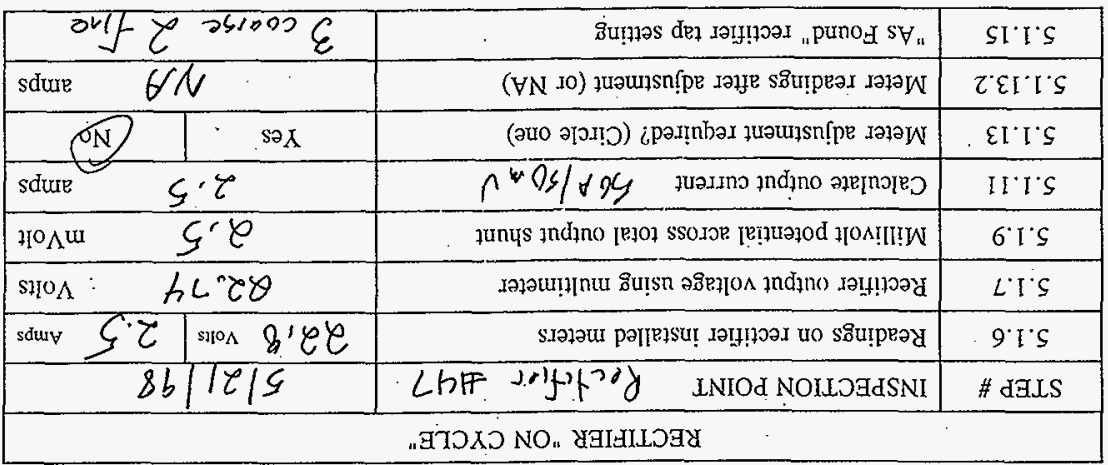

$\angle \varepsilon \cdot d$

$0 \cdot$ idd

$8+80^{\circ}- \pm N H$
(GGกNILNOD)

I LAGHS $\forall L \forall G$ 
TEST STATION: T(31-206)

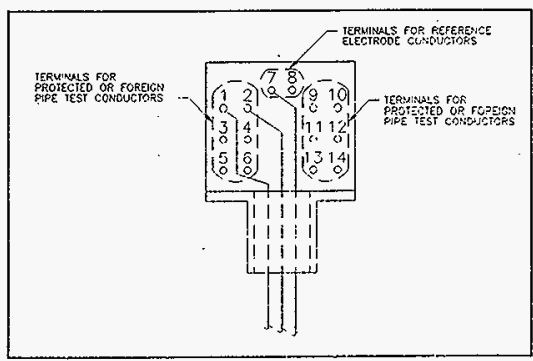

p. 38

\section{RESISTANCE ACROSS STRUCTURE TERMINALS}

PROCEDURE STEP: 5.2.2

\begin{tabular}{|c|c|c|c|}
\hline \multicolumn{2}{|c|}{ Test Terminals } & $\begin{array}{c}\text { Terminal Pair Label } \\
\text { (If Applicable) }\end{array}$ & $\begin{array}{c}\text { Resistance } \\
\text { (Ohms) }\end{array}$ \\
\hline 1 & 2 & & 8.1 \\
\hline 3 & 4 & & -3 \\
\hline
\end{tabular}

RESISTANCE BETWEEN STRUCTURES

PROCEDURE STEP: 5.2 .3

\begin{tabular}{|c|c|c|}
\hline \multicolumn{2}{|c|}{$\begin{array}{c}\text { Test Terminals } \\
\text { (One from each column, circle terminals used) }\end{array}$} & $\begin{array}{c}\text { Resistance } \\
\text { (0hms) }\end{array}$ \\
\hline (Dor 2 & 3)or 4 & 8.6 \\
\hline
\end{tabular}

POTENTIALS RELATIVE TO REFERENCE ELECTRODE

PROCEDURE STEP: 5.2 .4

\begin{tabular}{|c|c|c|c|}
\hline $\begin{array}{c}\text { Test Terminal } \\
\text { (circle Terminal Used) }\end{array}$ & $\begin{array}{c}\text { Reference } \\
\text { Electrode } \\
\text { Terminal }\end{array}$ & ON & OFF \\
\hline (Oor 2 & $(7)$ & 2.747 & 9.199 \\
\hline (3) or 4 & 0 & 2.748 & 1.213 \\
\hline
\end{tabular}

POTENTIALS RELATIVE TO PORTABLE ELECTRODE

PROCEDURE STEP: 5.2 .4
Portable to Reforence

ON .191

off .148

Test Enginger

\begin{tabular}{|c|c|}
\hline ON & OFF \\
\hline 2.937 & 1.343 \\
\hline 2.940 & 1.363 \\
\hline
\end{tabular}

$5 / 21 / 98$ 
TEST STATION: T(31-207) $H N F-2848$, Rev. O

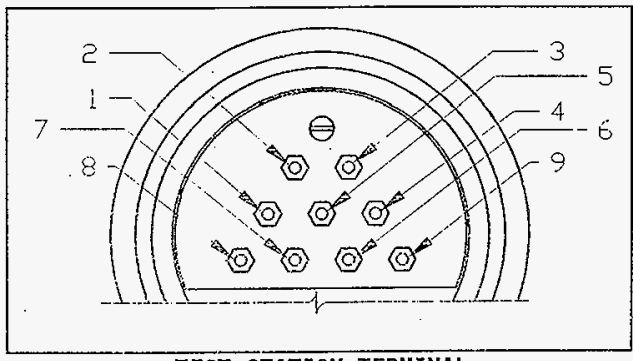
p. 39

TEST STATION TERMINAL

IDENTIFICATION DIAGRAM

RESISTANCE ACROSS STRUCTURE TERMINALS

PROCEDURE STEP: 5.2 .2

\begin{tabular}{|c|c|c|c|}
\hline \multicolumn{2}{|c|}{ Test Terminals } & $\begin{array}{c}\text { Terminal Pair Label } \\
\text { (If Applicable) }\end{array}$ & $\begin{array}{c}\text { Resistance } \\
\text { (0hms) }\end{array}$ \\
\hline 1 & 2 & $S-100$ & 60.6 \\
\hline 6 & 8 & $\rho S W-5505 \% \$ 2-2$ \\
\hline
\end{tabular}

PROCEDURE STEP: 5.2 .3

\begin{tabular}{|c|c|c|}
\hline \multicolumn{2}{|c|}{ Test Terminals } & $\begin{array}{c}\text { Resistance } \\
\text { (Ohms) }\end{array}$ \\
\hline (One from each column, circle terminals used) & $\theta, 4$ \\
\hline 1 or 2 & 6 or 8 & $\theta$ or \\
\hline
\end{tabular}

POTENTIALS RELATIVE TO REFERENCE ELECTRODE

PROCEDURE STEP: 5.2 .4

\begin{tabular}{|c|c|c|c|}
\hline $\begin{array}{c}\text { Test Terminal } \\
\text { (circle Terminal used) }\end{array}$ & $\begin{array}{c}\text { Reference } \\
\text { Electrode } \\
\text { Terminal }\end{array}$ & ON & $0.222 \quad 0.11$ \\
\hline (Dor 2 & 5 & .836 & .594 \\
\hline (2) or 8 & 0 & $: 836$ & .595 \\
\hline
\end{tabular}

POTENTIALS RELATIVE TO PORTABLE ELECTRGDE

PROCEDURE STEP: 5.2.4

\begin{tabular}{|c|c|c|}
\hline $\begin{array}{l}\text { Test Terminal } \\
\text { (circle Jerminal Used) }\end{array}$ & ON & OFF \\
\hline 1) or 2 & 1.058 & .701 \\
\hline (6) or 8 & 1.062 & .709 \\
\hline $7: 2,1$ & or & $5 / 21$ \\
\hline
\end{tabular}


TEST STATION: T(46-1)

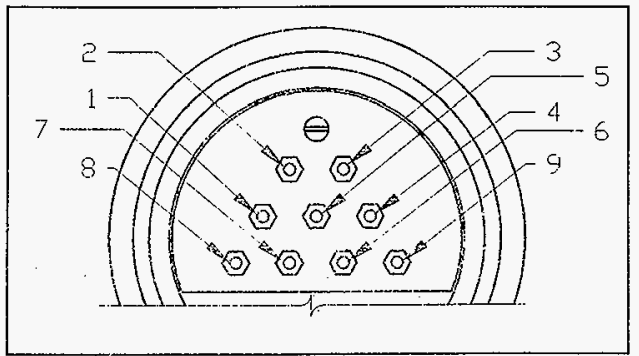

p. 40

\section{TEST STATION TERMINAL \\ IDENTIFICATION DIAGRAM}

RESISTANCE ACROSS STRUCTURE TERMINALS

PROCEDURE STEP: 5.2 .2

\begin{tabular}{|c|c|c|c|}
\hline \multicolumn{2}{|c|}{ Test Terminals } & $\begin{array}{c}\text { Terminal Pair Labe] } \\
\text { (If Applicable) }\end{array}$ & $\begin{array}{c}\text { Resistance } \\
\text { (Ohms) }\end{array}$ \\
\hline 1 & 2 & $S \angle-100$ & .4 \\
\hline 3 & 4 & $S N-200$ & .4 \\
\hline
\end{tabular}

RESISTANCE BETWEEN STRUCTURES

PROCEDURE STEP: 5.2 .3

Test Terminals

(One from each column, circle terminals used)

1 or (2)

(3) or 4

Resistance (Ohins)

POTENTIALS RELATIVE TO REFERENCE ELECTRODE

PROCEDURE STEP: 5.2 .4

\begin{tabular}{|c|c|c|c|}
\hline $\begin{array}{c}\text { Test Terminal } \\
\text { (circle Terminat used) }\end{array}$ & $\begin{array}{c}\text { Reference } \\
\text { Electrode } \\
\text { Terminal }\end{array}$ & ON & OFF \\
\hline (Dor 2 & 5 & 3.450 & $/ .3 / 5$ \\
\hline (3) or 4 & 5 & 3.450 & $/ .3 / 3$ \\
\hline
\end{tabular}

POTENTIALS RELATIVE TO PORTABLE ELECTRODE

PROCEDURE STEP: 5.2.4

\begin{tabular}{|c|c|c|c|}
\hline Test Terminal & ON & OFF & \multirow{4}{*}{$\begin{array}{l}\text { on } \quad+3 \frac{19}{R G} 1.330 \\
\text { of } 0.137\end{array}$} \\
\hline (Circle Terminal Used) & & & \\
\hline Q or 2 & 3.911 & 1.421 & \\
\hline (3) or 4 & 3.911 & 1.423 & \\
\hline 7.2 .60 & & $5 / 21)$ & \\
\hline
\end{tabular}




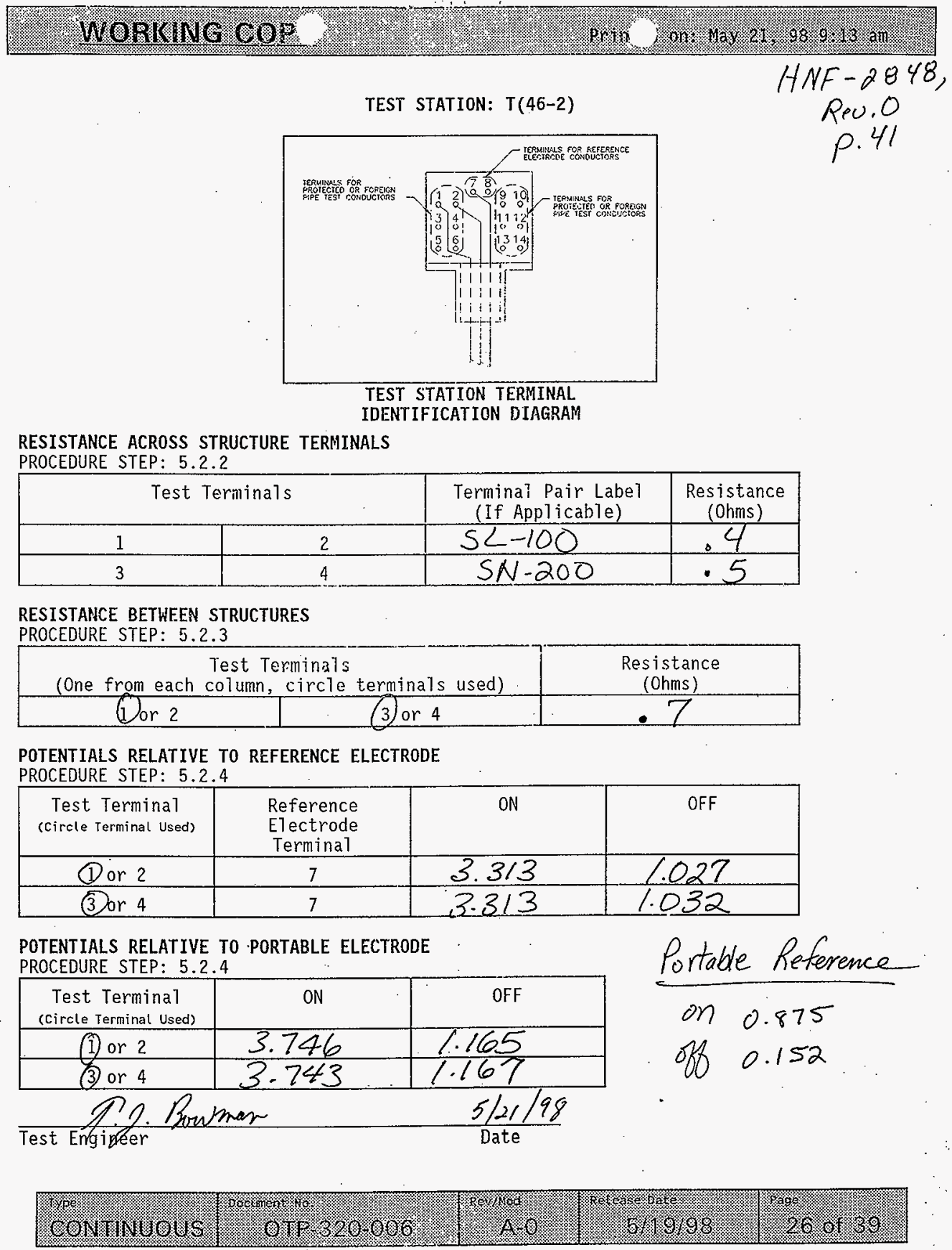


TEST STATION: T(46-3)

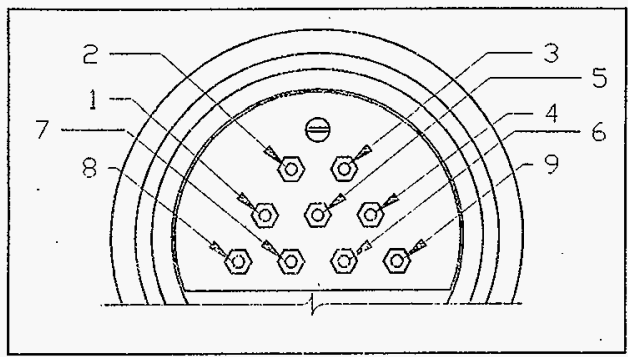

\section{TEST STATION TERMINAL \\ IDENTIFICATION DIAGRAM}

RESISTANCE ACROSS STRUCTURE TERMINALS

PROCEDURE STEP: 5.2 .2

\begin{tabular}{|c|c|c|c|}
\hline \multicolumn{2}{|c|}{ Test Terminals } & $\begin{array}{c}\text { Terminal Pair Label } \\
\text { (If App7icab]e) }\end{array}$ & $\begin{array}{c}\text { Resistance } \\
\text { (Ohms) }\end{array}$ \\
\hline 1 & 2 & $S N-200$ & 22.1 \\
\hline 3 & 4 & $S \leftarrow-200$ SL100 & 4.2 \\
\hline
\end{tabular}

RESISTANCE BETWEEN STRUCTURES

PROCEDURE STEP: 5.2 .3

\begin{tabular}{|c|c|c|}
\hline \multicolumn{2}{|c|}{$\begin{array}{c}\text { Test Terminals } \\
\text { (One from each column, circle terminals used) }\end{array}$} & $\begin{array}{c}\text { Resistance } \\
\text { (Ohms) }\end{array}$ \\
\hline 1 or $(2)$ & 3) or 4 &, 9 \\
\hline
\end{tabular}

\section{POTENTIALS RELATIVE TO REFERENCE ELECTRODE}

PROCEDURE STEP: 5.2.4

\begin{tabular}{|c|c|c|c|}
\hline $\begin{array}{c}\text { Test Terminal } \\
\text { (circle Terminal Used) }\end{array}$ & $\begin{array}{c}\text { Reference } \\
\text { Electrode } \\
\text { TerminaT }\end{array}$ & ON & OFF \\
\hline Dor 2 & 5 & 1.032 & 0.656 \\
\hline 3or 4 & 5 & 1.039 & 0.655 \\
\hline
\end{tabular}

POTENTIALS RELATIVE TO PORTABLE ELECTRODE PROCEDURE STEP: 5.2.4

\begin{tabular}{|c|c|c|}
\hline $\begin{array}{l}\text { Test Terminat } \\
\text { (Circle Terminal Used) }\end{array}$ & ON & $\begin{array}{l}\text { OFF } \\
800\end{array}$ \\
\hline (1) or 2 & 1.508 & 0.785 \\
\hline (3) or 4 & 1.515 & 0.797 \\
\hline
\end{tabular}

Portable to Perimannt on 0.0477

of 0.138 
TEST STATION: T(46-4)

HNF-2848,

Reu.0

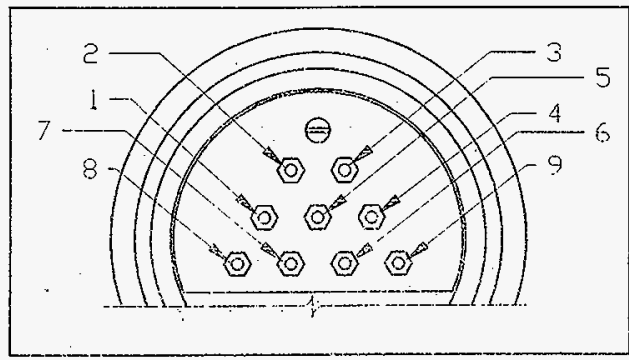

p. 43

TEST STATYON TERMINAL

IDENTIFICATION DIAGRAM

RESISTANCE ACROSS STRUCTURE TERMINALS

PROCEDURE STEP: 5.2 .2

\begin{tabular}{|c|c|c|c|}
\hline \multicolumn{2}{|c|}{ Test Terminals } & $\begin{array}{c}\text { Terminal Pair Label } \\
\text { (If Applicable) }\end{array}$ & $\begin{array}{c}\text { Resistance } \\
\text { (ohms) }\end{array}$ \\
\hline 1 & 2 & $5<-100$ & .3 \\
\hline 3 & 4 & $S N-200$ & .3 \\
\hline
\end{tabular}

RESISTANCE BETWEEN STRUCTURES

PROCEDURE STEP: 5.2 .3

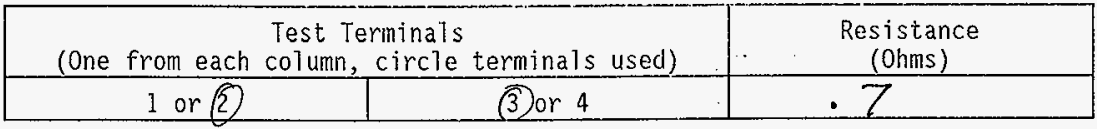

POTENTIALS RELATIVE TO REFERENCE ELECTRODE

PROCEDURE STEP: 5.2.4

\begin{tabular}{|c|c|c|c|}
\hline $\begin{array}{c}\text { Test Terminal } \\
\text { (circle Terminal Used) }\end{array}$ & $\begin{array}{c}\text { Reference } \\
\text { Electrode } \\
\text { Terminal }\end{array}$ & ON & OFF \\
\hline (1)or 2 & 5 & 3.067 & 0.968 \\
\hline 3)or 4 & 5 & 3.065 & 0.968 \\
\hline
\end{tabular}

POTENTIALS RELATIVE TO PORTABLE ELECTRODE

PROCEDURE STEP: 5.2 .4

\begin{tabular}{|c|c|c|c|}
\hline $\begin{array}{c}\text { Test Terminal } \\
\text { (Circle Terminal Used) }\end{array}$ & ON & OFF & on -.187 \\
\hline Dor 2 & 2.878 & 0.968 & 0.013 \\
\hline (3) or 4 & 2.880 & 0.969 & oft \\
\hline
\end{tabular}




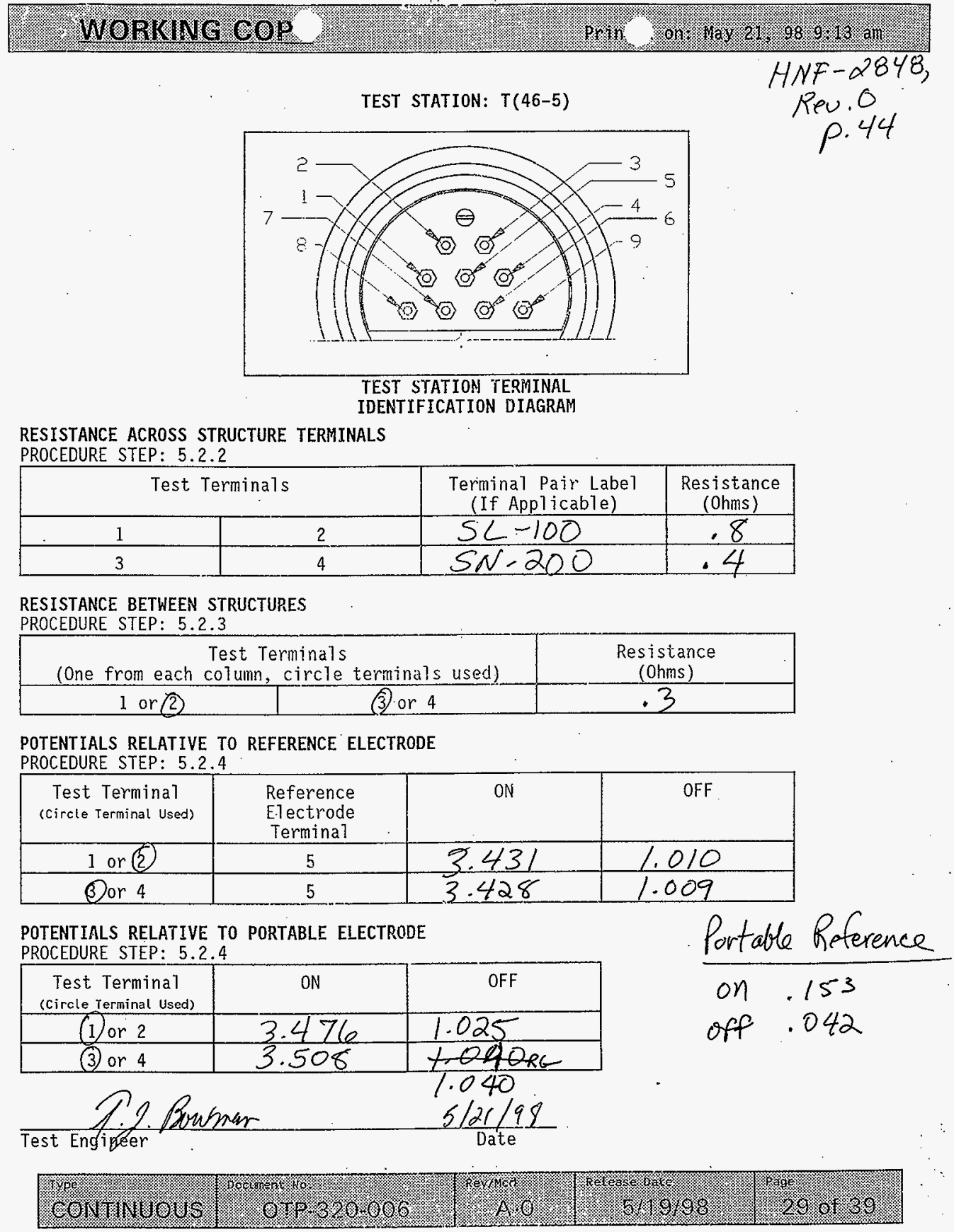




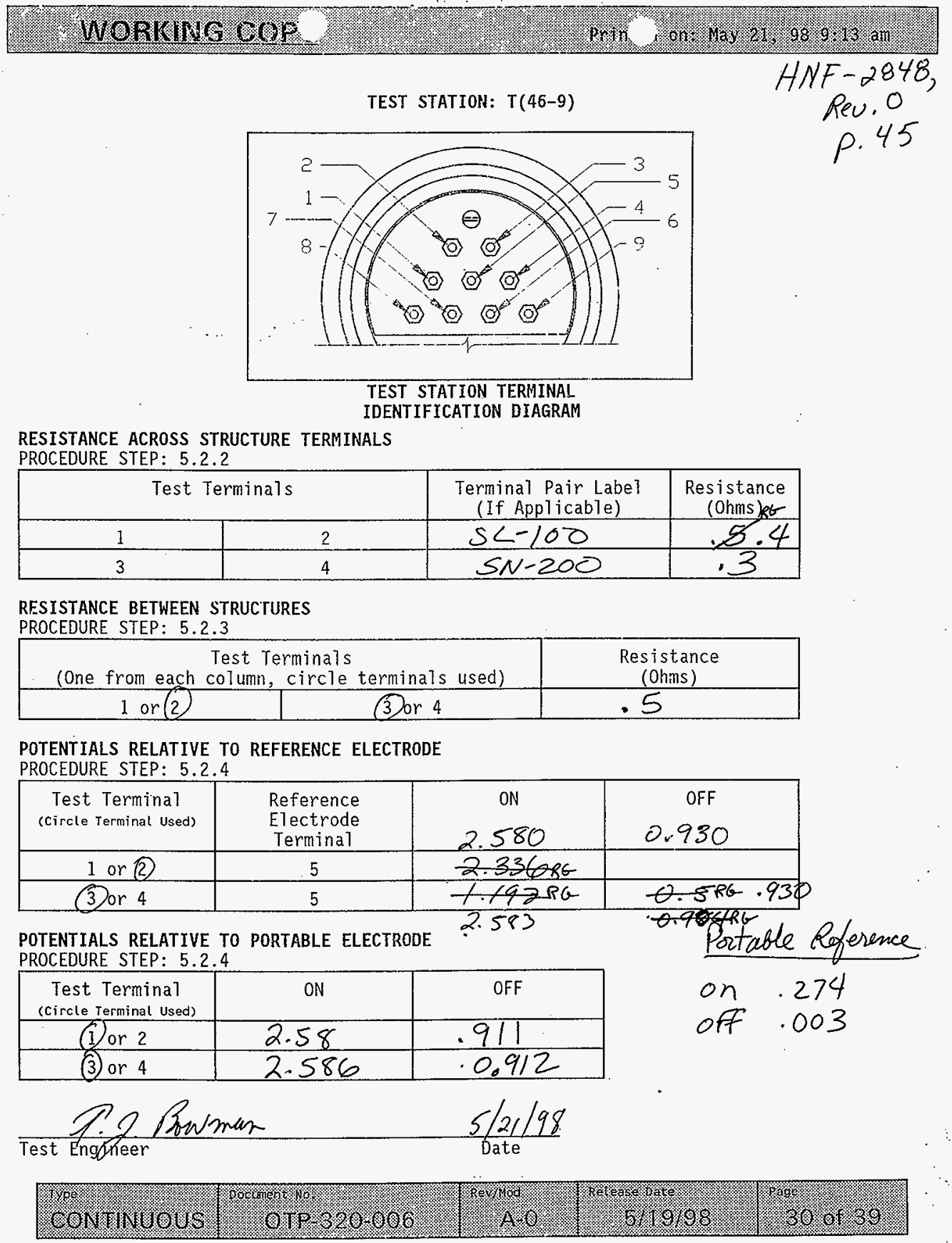




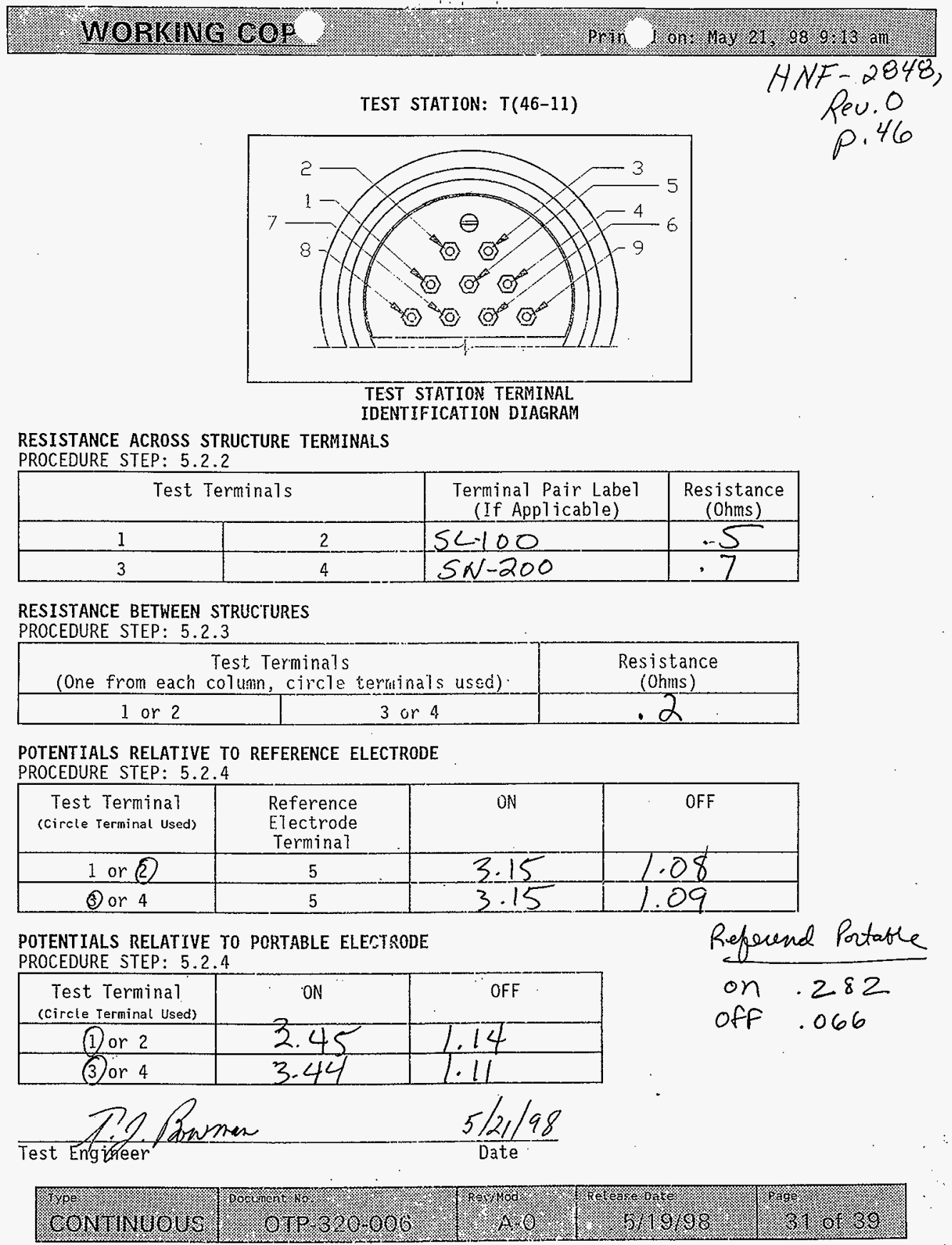


TEST STATION: T(46-14)

HNF-2848,

Rev. O

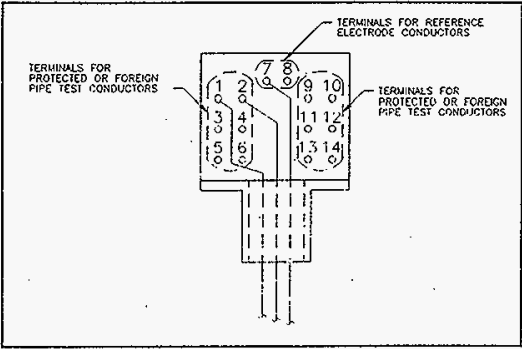

p. 47

TEST STATION TERMINAL

IDENTIFICATION DIAGRAM

RESISTANCE ACROSS STRUCTURE TERMINALS

PROCEDURE STEP: 5.2 .2

\begin{tabular}{|c|c|l|c|}
\hline \multicolumn{2}{|c|}{ Test Terminals } & $\begin{array}{c}\text { Terminal Pair Label } \\
\text { (If Applicable) }\end{array}$ & $\begin{array}{c}\text { Resistance } \\
\text { (Ohms) }\end{array}$ \\
\hline 1 & 2 & $S<100$ & .3 \\
\hline 3 & 4 & $S N 200$ & .4 \\
\hline
\end{tabular}

RESISTANCE BETWEEN STRUCTURES

PROCEDURE STEP: 5.2 .3

\begin{tabular}{|c|c|c|}
\hline \multicolumn{2}{|c|}{ Test Terminals } & $\begin{array}{c}\text { Resistance } \\
\text { (Ohms) }\end{array}$ \\
\hline (One from each column, circle terminals used) & .4 \\
\hline (1) 2 & (3) or 4 & .4 \\
\hline
\end{tabular}

POTENTIALS RELATIVE TO REFERENCE ELECTRODE PROCEDURE STEP: 5.2 .4

\begin{tabular}{|c|c|c|c|}
\hline $\begin{array}{c}\text { Test Terminal } \\
\text { (circle Terminat Used) }\end{array}$ & $\begin{array}{c}\text { Reference } \\
\text { Electrode } \\
\text { Terminal }\end{array}$ & ON & OFF \\
\hline (1) 2 & $(7)$ & 4.42 & 1.48 \\
\hline (3) or 4 & $(7)$ & 4.41 & 1.45 \\
\hline
\end{tabular}

POTENTIALS RELATIVE TO PORTABLE ELECTRODE PROCEDURE STEP: 5.2 .4

\begin{tabular}{|c|c|c|}
\hline $\begin{array}{c}\text { Test Terminal } \\
\text { (circle Terminal Used) }\end{array}$ & ON & OFF \\
\hline (1)or 2 & 8.290 & 2.040 \\
\hline 3) 4 & 8.290 & 2.110 \\
\hline
\end{tabular}

$5 / 21 / 98$

Date
Reference Pootoble on 3.880 off $\begin{gathered}0.050-R G / u / 9 \\ 0.620\end{gathered}$ 


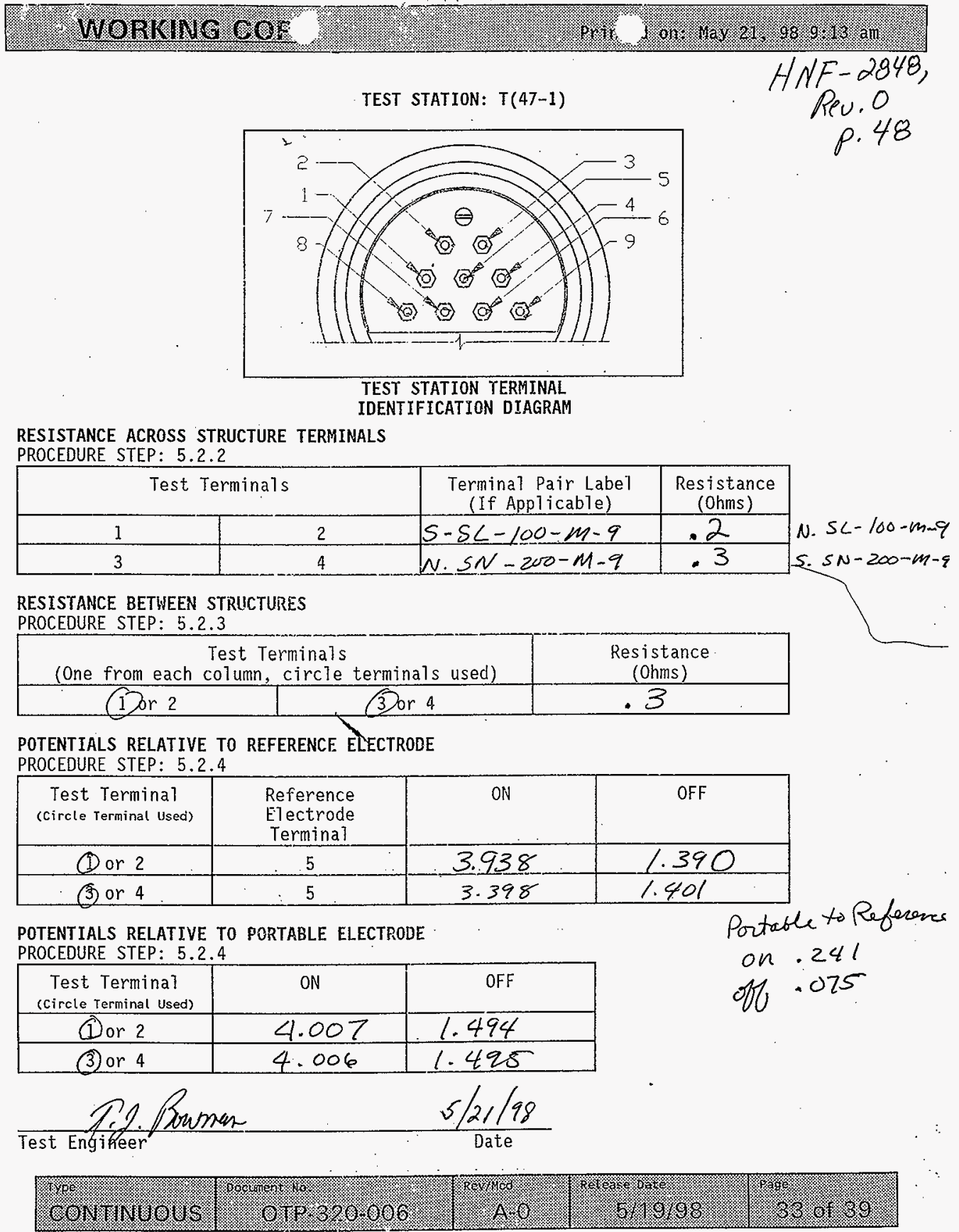


TEST STATION: $T(47-2)$

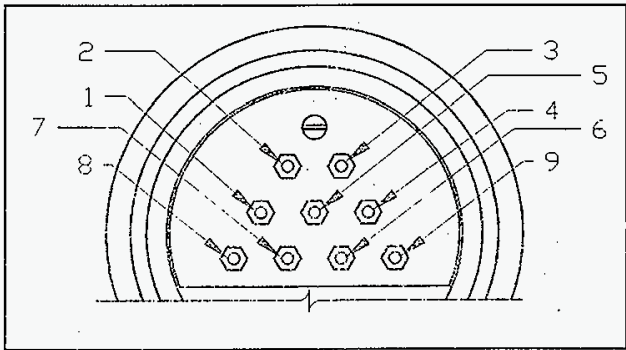

\section{TEST STATION TERMINAL \\ IDENTIFICATION DIAGRAM}

HNF-2848,

Rev. O

p. 49

RESISTANCE ACROSS STRUCTURE TERMINALS

PROCEDURE STEP: 5.2 .2

\begin{tabular}{|c|c|c|c|}
\hline \multicolumn{2}{|c|}{ Test Terminals } & $\begin{array}{c}\text { Terminal Pair Label } \\
\text { (If Applicable) }\end{array}$ & $\begin{array}{c}\text { Resistance } \\
\text { (0hms) }\end{array}$ \\
\hline 1 & 2 & 5.5 L $900-m-9$ & 19.2 \\
\hline 3 & 4 & NO LABELS & $0.54-100-m-9$ \\
\hline
\end{tabular}

RESISTANCE BETWEEN STRUCTURES

PROCEDURE STEP: 5.2 .3

\begin{tabular}{|c|c|c|}
\hline \multicolumn{2}{|c|}{$\begin{array}{c}\text { Test Terminals } \\
\text { (One from each column, circle terminals used) }\end{array}$} & $\begin{array}{c}\text { Resistance } \\
\text { (Ohms) }\end{array}$ \\
\hline (1) or 2 & (3) or 4 & 3.2 \\
\hline
\end{tabular}

\section{POTENTIALS RELATIVE TO REFERENCE ELECTRODE}

PROCEDURE STEP: 5.2 .4

\begin{tabular}{|c|c|c|c|}
\hline $\begin{array}{c}\text { Test Terminal } \\
\text { (circle Terminal used) }\end{array}$ & $\begin{array}{c}\text { Reference } \\
\text { Electrode } \\
\text { Terminal }\end{array}$ & ON & OFF \\
\hline 1 or (2) & $(5)$ & 2.625 & 1.170 \\
\hline (3) or 4 & 5 & 2.625 & 1.712 \\
\hline
\end{tabular}

POTENTIALS RELATIVE TO PORTABLE ELECTRODE

PROCEDURE STEP: 5.2 .4

\begin{tabular}{|c|c|c|}
\hline $\begin{array}{c}\text { Test Terminal } \\
\text { (circle Terminal Used) }\end{array}$ & ON & OFF \\
\hline 1 or (2) & 1.434 & 1.187 \\
\hline (3) or 4 & 1.435 & 1.184 \\
\hline
\end{tabular}

Portable to Refereme on -1.189 off 0.101

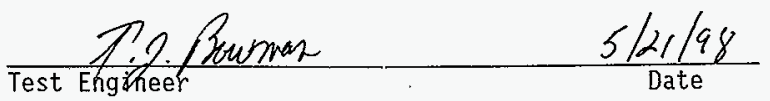


TEST STATION: $T(47-3)$

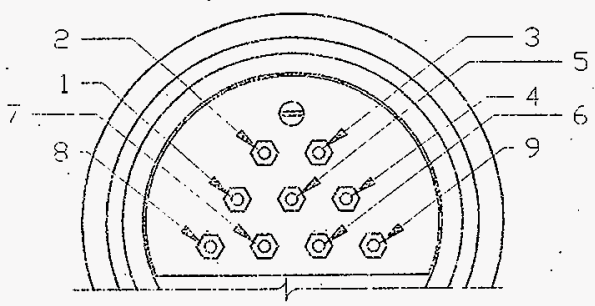

\section{TEST STATION TERMINAL \\ IDENT IFICATION DIAGRAM}

RESISTANCE ACROSS STRUCTURE TERMINALS

PROCEDURE STEP: 5.2 .2

\begin{tabular}{|c|c|c|c|}
\hline \multicolumn{2}{|c|}{ Test Terminals } & $\begin{array}{c}\text { Termina? Pair Label } \\
\text { (If Applicable) }\end{array}$ & $\begin{array}{c}\text { Resistance } \\
\text { (Ohms) }\end{array}$ \\
\hline 1 & 2 & E $5<-100-m 9$ & .2 \\
\hline 3 & 4 & Pipe does not oxist. \\
\hline
\end{tabular}

RESISTANCE BETHEEN STRUCTURES Portable to permanent -.018 fo on PROCEDURE STEP: 5.2 .3

\begin{tabular}{|c|c|c|}
\hline \multicolumn{2}{|c|}{$\begin{array}{c}\text { Test Terminals } \\
\text { (One from each column, circle terminals used) }\end{array}$} & $\begin{array}{c}\text { Resistance } \\
\text { (Ohms) }\end{array}$ \\
\hline 1 or 2 & 3 or 4 & \\
\hline
\end{tabular}

\section{POTENTIALS RELATIVE TO REFERENCE ELECTRODE}

PROCEDURE STEP: 5.2 .4

\begin{tabular}{|c|c|c|c|}
\hline $\begin{array}{c}\text { Test Terminal } \\
\text { (circle Terminal Used) }\end{array}$ & $\begin{array}{c}\text { Reference } \\
\text { Electrode } \\
\text { Termina] }\end{array}$ & ON & OFF \\
\hline (1) 2 & $\widehat{5}$ & 2.541 & 1.194 \\
\hline 3 or 4 & 5 & & \\
\hline
\end{tabular}

POTENTIALS RELATIVE TO PORTABLE ELECTRODE

PROCEDURE STEP: 5.2 .4

\begin{tabular}{|c|c|c|}
\hline $\begin{array}{c}\text { Test Terminat } \\
\text { (circle Terminal Used) }\end{array}$ & ON & $\mathrm{OFF}$ \\
\hline (1)or 2 & 2.291 & 1.223 \\
\hline 3 or 4 & & \\
\hline D.2. & 254 & $\begin{array}{l}7.7 q 4 R G|21| q 1 \\
5 / 21 / 98\end{array}$ \\
\hline
\end{tabular}

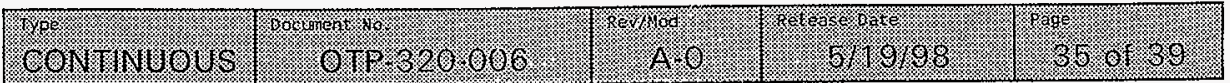


TEST STATION: T(47-4)

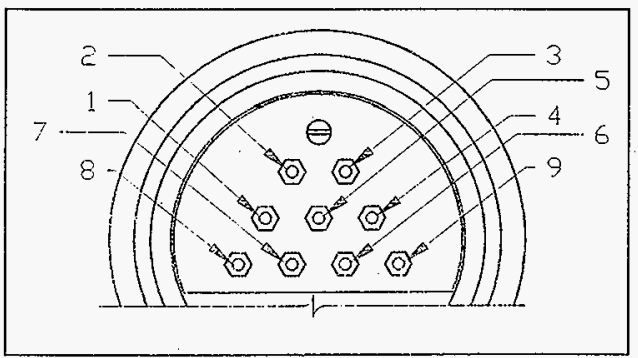

TEST STATION TERMINAL

IDENTIFICATION DIAGRAM

HNF-2848,

Peu. 0

p. 51

RESISTANCE ACROSS STRUCTURE TERMINALS

PROCEDURE STEP: 5.2 .2

\begin{tabular}{|c|c|c|c|}
\hline \multicolumn{2}{|c|}{ Test Terminals } & $\begin{array}{c}\text { Terminal Pair Label } \\
\text { (If Applicable) }\end{array}$ & $\begin{array}{c}\text { Resistance } \\
\text { (Ohms) }\end{array}$ \\
\hline 1 & 2 & E.OR-30//m-9 & .2 \\
\hline 6 & 7 & W.SN. 200-mq & .2 \\
\hline
\end{tabular}

RESISTANCE BETWEEN STRUCTURES

PROCEDURE STEP: 5.2 .3

Test Terminals

(One from each column, circle terminals used)

(1) 2

(6) 7

Resistance (0hms)

11.6

POTENTIALS RELATIVE TO REFERENCE ELECTRODE

PROCEDURE STEP: 5.2.4

\begin{tabular}{|c|c|c|c|}
\hline $\begin{array}{c}\text { Test Termina1 } \\
\text { (circle Terminal used) }\end{array}$ & $\begin{array}{c}\text { Reference } \\
\text { Electrode } \\
\text { Termina] }\end{array}$ & ON & OFF \\
\hline (Dor 2 & (5)or 8 & 3.929 & 1.419 \\
\hline 6) or 7 & (5)or 8 & 3.930 & 1.416 \\
\hline
\end{tabular}

POTENTIALS RELATIVE TO PORTABLE ELECTRODE.

PROCEDURE STEP: 5.2.4

\begin{tabular}{|c|c|c|}
\hline $\begin{array}{c}\text { Test Terminal } \\
\text { (Circle Terminal Used) }\end{array}$ & ON & OFF \\
\hline Qor 2 & 3.690 & 1.206 \\
\hline 6 or 7 & 3.689 & 1.201 \\
\hline
\end{tabular}

$$
\begin{gathered}
\text { ON } \\
-.606 \\
.0 F F \\
-.205
\end{gathered}
$$




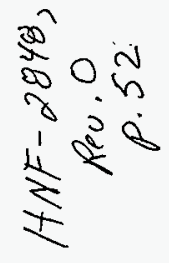

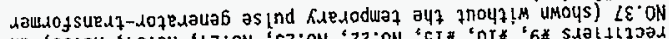
pue " $G E$ " ON "

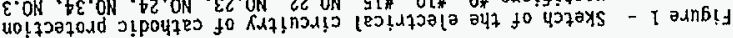

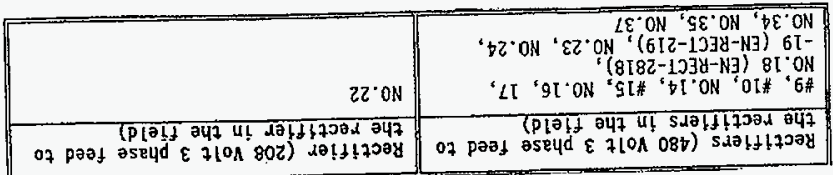

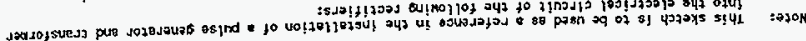

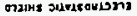

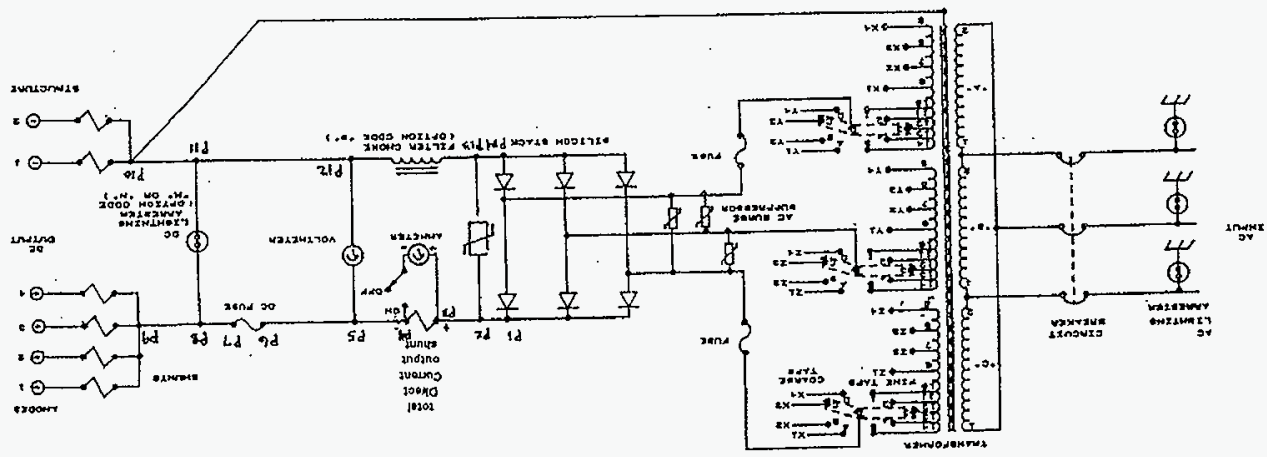


FIGURE 2 - PULSE GENERATOR - TRANSFORMER CONFIGURATION

Hote: For POCrifiers 0.16 HO 16,17 HO 18 (EH-RECT-2818), and $-10^{\circ}$ (EH-RECT-219) - a DUAL VOL TAGE IHPUT

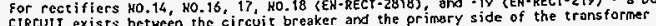

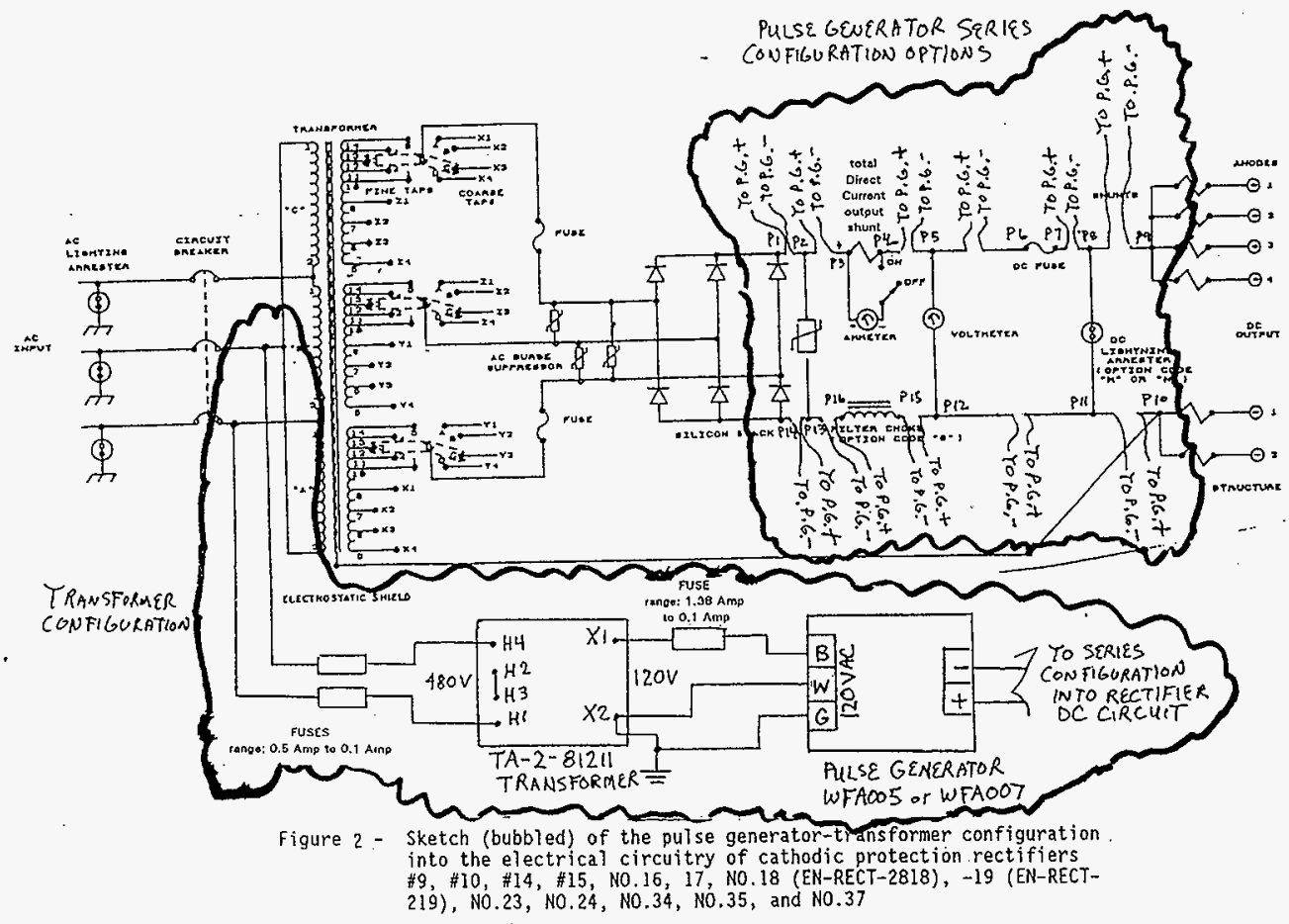

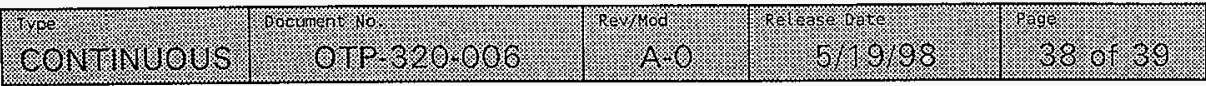




\section{PROCEDURE HISTORY SIGNATURE SHEET}

$$
\begin{gathered}
\text { HNF-2848, } \\
\text { Peu. } 0 \\
p .54
\end{gathered}
$$

